\title{
Clay Mineralogy and Geochemistry of Fossil and Active Hydrothermal Alteration in the Hisaralan Geothermal Field (Sındırgı-Balıkesir), western Turkey
}

\author{
Cumhur KOCABAŞ ${ }^{1}$, Murat TOKÇAER ${ }^{2}$, and Mümtaz ÇOLAK ${ }^{2}$ \\ ${ }^{1}$ Balıkesir University, Department of Geological Engineering, Çă̆ıs Campus, 10145, Balıkesir. \\ ${ }^{2}$ Dokuz Eylül University, Department of Geological Engineering Tinaztepe Campus, 35160, Buca, izmir. \\ e-mail.cumhur.kocabas@balikesir.edu.tr, murat.tokcaer@deu.edu.tr,mumtaz.colak@deu.edu.tr
}

Geliş Tarihi: 22.12.2015; Kabul Tarihi;17.02.2016

\section{Abstract}

Keywords

Volcanics; Geothermal; Hydrothermal Alteration; Mixed Layer IlliteSmectite; Smectite.

\begin{abstract}
Hisaralan geothermal field is located at the intersection between Simav Graben and Izmir-Balıkesir Transfer Zone (IBTZ). The area is hosted by Early Miocene dacitic and rhyolitic volcanics. Clay mineralogy was investigated for the purpose of identifying the present and fossil hydrothermal systems. HS-2 drillhole and surface clay mineralogy were examined by XRD, SEM and optical microscopy. R2 I-S and smectite are dominant clay mineral close to the surface while discerete illite and R3 I-S are the dominant clay minerals at the deeper parts of the geothermal field. The fossil hydrothermal system developed at two stages. Initially, Fe-rich chlorite, calcite and pyrite indicative of propylitic alteration occurred. Subsequently, discrete illite and I-S postdated the propylitic alteration. $\mathrm{Rb} / \mathrm{Sr}$ isotope data from illitic minerals (illite and/or I-S) shows they are coeval and cogenetic with Early Miocene volcanism. On the other hand, active hydrothermal system is supposed to precipitate dioctahedral smectite. Activity of elements indicates the thermal waters are in equilibrium with smectite at temperatures below $100{ }^{\circ} \mathrm{C}$. Halloysite found in the cracks and coating on the surfaces of former alteration products indicates a late phase precipitation. $\mathrm{O}$ and $\mathrm{H}$ isotopes of clay minerals indicate that low temperature geothermal systems precipitate clay minerals as smectite, and intersection of fault zones are characteristic for present day geothermal fluids Hisaralan and its surroundings.
\end{abstract}

\section{Hisaralan (Sındırgı-Balıkesir-Batı Anadolu) Jeotermal Sahasında Fosil ve Aktif Hidrotermal Alterasyonun Kil Mineralojisi ve Jeokimyası}

\begin{abstract}
Özet
Hisaralan jeotermal sahası Simav Grabeni ile İzmir-Balıkesir Transfer Zonu (IBTZ)'nin kesişim yerinde bulunmaktadır. Alan Erken Miyosen dasidik ve riyolitik volkaniklerden oluşmaktadır. Kil mineralojisi güncel ve fosil hidrotermal alterasyonu belirlemek için araştırılmıştır. HS-2 sondaj kuyusu ve yüzey örneklerinin mineralojisi XRD, SEM ve optik mikroskop ile çalışılmıştır. R2 I-S ve simektit yüzeye yakın kesimlerde baskınken saf illit ve R3 I-S jeotermal alanın derin kesimlerdeki baskın kil mineralleridir. Fosil hidrotermal sistem iki evrede gerçekleşmiştir. Illk olarak, piropilitik alterasyonu işaret eden Fe-zengin klorit, kalsit ve pirit oluşmuştur. Bunu takip eden, saf illit ve illitçe zengin I-S piropilitik alterasyonu üzerlemiştir. $\mathrm{Rb} / \mathrm{Sr}$ izotop verileri illitik minerallerin (illit ve/veya I-S) Erken Miyosen volkanizması ile yaş ve köken bakımında eş olduğunu göstermektedir. Diğer taraftan, aktif hidrotermal alterasyonun dioktahedral simektit çökelttiği varsayılmaktadır. Element aktiviteleri termal suların $100^{\circ} \mathrm{C}$ ve altında simektit ile dengede olduğunu göstermektedir. Çatlaklarda ve önceki alterasyon ürünlerinin yüzeyinde sıvamalar şeklinde bulunan halloysit geç evre oluşumudur. Killere ait $\mathrm{O}$ ve $\mathrm{H}$ izotop verileri simektit mineralinin aktif jeotermal sisteme ait olduğunu ve halloysitin meteorik kökenli düşük sıcaklıklı sulardan çökeldiğine işaret eder. Düşük sıcaklıklı jeotermal sistemler simektit çökeltmektedir ve fay zonlarının kesişim yerleri Hisaralan ve çevresindeki güncel jeotermal alanlar için karakteristiktir.

Anahtar kelimeler

Volkanik; Jeotermal; Hidrotermal Alterasyon; Karışık tabakalı IllitSmectit; Simektit.




\section{Introduction}

WNW-ESE trending Simav Graben is the latest products of $\mathrm{N}-\mathrm{S}$ extentional tectonics (Seyitoğlu, 1997). Kaolin, alunite and epithermal ore deposits are regarded as products of fossil hydrothermal systems and coeval and cogenetic with Miocene volcanism along Simav Graben (Oygür and Erler, 2000; Mutlu and Sariz, 2005; Ece et al. 2013; Yılmaz et al. 2013). In addition to fossil hydrothermal alteration active geothermal systems are characterised by sinter precipitations and hot springs (Oygür \& Erler, 2000). Hydrothermal alteration in Hisaralan geothermal field is an example for existing of both past and present hydrothermal alteration where active Simav graben faults meets with NE-SW trending strike slip faults.

Dioctahedral clay minerals such as smectite, mixed layer illite-smectite (I-S) and ilite provides information about thermal and geochemical conditions of hydrothermal alteration both in extinct and active geothermal systems (Inoue et al. 2004). Smectite to illite transition via mixed layered I-S is considered to be used as geothermometer in geothermal fields (Horton, 1985; Beaufort et al. 1990; Harvey and Brown 1991; Inoue, 2004). On the other hand, factors such as fluid chemistry, time and $W / R$ ratio are important factors affecting the formation of I-S. Although using clay minerals as a geothermometer is controversial (Essene and Peacor, 1995), smectite, I-S, illite and aqueous solutions can be attained equilibrium and activities of components can be used (Aagard and Helgeson, 1983; Aja, 1992).

Our ettempt is to characterize the clay mineral assemblage in Hisaralan geothermal field to seperate active and fossil hydrothermal systems. For this reason, the relation between the solid phases and aqueous solutions are compared. $\mathrm{O}$ and $\mathrm{H}$ isotopic compositions of clay minerals and chemistry of fluids should be used for separation of active and fossil geothermal systems.

\section{Materials and Methods}

Surface samples were collected $30-40 \mathrm{~cm}$ beneath the surface to eliminate the weathering effects. Whole rock and clay mineralogy were determined by X-ray diffraction (XRD) using a Phillips X'Pert Pro diffractometer with $\mathrm{Ni}$-filtred, CuK $\alpha$ radiation. Scanning speed was $1^{\circ} 2 / \mathrm{min}$. The clay mineralogy was determined after separating $<2 \mu \mathrm{m}$ fraction in distilled water by santrifuge method. The clay fraction was spread on glass slides. XRD analyses were carried out on air dried, and ethylene glycole saturated samples (Brown and Brindley, 1980).

The morphology of clays as well as other secondary minerals were examined by using scanning electron microscope (SEM) FEI Quanta 250 FEG equipped with an energy-dispersive spectroscopy (EDS). Microanalyses were performed on gold coated samples.

Whole rock chemical analyses were carried out by inductively coupled plasma emission spectrometry (ICP-MS) following a lithiumborate fusion and dilute acid digestion of a 0,2 $\mathrm{g}$ sample in ACME Analytical Laboratories (Canada).

Element analyses of water samples were carried out by ICP-MS (ACME, Canada). Two polyethlene bottles of water were collected for each sample. The waters have been passed on a $0.45 \mu \mathrm{m}$ filter paper. One of them was acidified with concentrated $\mathrm{HNO}_{3}$ for cation analyses. No preservation was made to the other bottle collected for anion analyses. Temperature, $\mathrm{pH}$, Eh ,electrical conductivity (EC) and $\mathrm{HS}^{-}$were determined in-situ. Bicarbonate was determined in the field by titration method using $0,1 \mathrm{M} \mathrm{HCl}$ to prevent changes as a function of $\mathrm{pH}$. The activity of elemens were calculated by PHREEQC computer code. The diagrams were selected on the basis of clay mineralogy of the outcrop and drillinghole samples. 
The mobility of elements are determined by comparing the chemical composition of the fresh rock with respect to altered rocks (Gresens, 1967). The mass change was taken into consideration and following simplified equation was used (Grant, 1986, MacLean and Kranidiotis, 1987). $\Delta C_{i}=\left(C_{x}{ }^{P} C_{i}{ }^{D} / C_{x}{ }^{D}\right)-C_{i}{ }^{P}$. If $\Delta C_{i}=0$ which indicates immobility, $C_{i}^{P}$ should be taken to the left side of the equation for the purpose of evaluating the mobility of elements in a logaritmic scale the following calculation is used; $C_{i}{ }^{p} /\left(C_{x}{ }^{P} C_{i}{ }^{D} / C_{x}{ }^{D}\right)=1$ which indicates immobility. $\mathrm{Al}_{2} \mathrm{O}_{3}$ is taken immobile by binary plot of immobile elements which displays a linear line passing from the origin. $\mathrm{C}_{\mathrm{i}}^{\mathrm{P}}$ and $\mathrm{C}_{\mathrm{i}}^{\mathrm{D}}$ represents concentration of element in the fresh and altered rock respectively. $C_{x}{ }^{P}$ and $C_{x}{ }^{D}$ represents concentration of immobile component $\mathrm{Al}_{2} \mathrm{O}_{3}$.

Oxygen and hydrogen isotopic composition of clay minerals were determined using the analytical techniques of Clayton and Mayeda (1963). The hydrogen isotope analysis of clay minerals was carried out on a Thermo Finnigan TC-EA interfaced with a Thermo Finnigan Delta-Plus XL mass spectrometer, using the reference materials NBS22 (oil; $\delta D_{\text {SMOW }}=-117 \%$ o), IAEA-CH-7 (polyethylene foil; $\delta D_{\text {sMow }}=-100 \%$ ) and an inhouse standard (kaolinite; $\delta D_{\text {smow }}=-65 \%$ ). The oxygen isotope analysis was carried out using a laser fluorination line interfaced with a Finnigan MAT 252 mass spectrometer, using UWG-2 garnet $\left(\delta^{18} \mathrm{O}=5.8 \%\right.$ ) (Valley et al., 1995) as reference material. The analytical precision was $1 \%$ for the $\mathrm{dD}$ measurements and $0.2 \%$ for the ${ }^{18} \mathrm{O}$ measurements.

${ }^{18} \mathrm{O}$ and $\mathrm{D} / \mathrm{H}$ isotope ratios in liquid water samples using a Laser Water Isotope Analyzer V2. For ${ }^{18} \mathrm{O}$ and $\mathrm{D} / \mathrm{H}$ at natural abundance, each sample is injected 8 times. The first 4 injections are discarded to eliminate memory effects and the average of injections \# 5-8 is used for isotope ratio calculations. Sample isotope ratios are standardized using a range of working standards that have been calibrated against IAEA standard reference materials (VSMOW, GISP, and SLAP). Precision for water samples at natural abundance is typically $\leq 0.3$ permil for ${ }^{18} \mathrm{O}$ and $\leq 0.8$ permil for $\mathrm{D} / \mathrm{H}$. Final ${ }^{18} \mathrm{O} /{ }^{16} \mathrm{O}$ and $\mathrm{D} / \mathrm{H}$ values are reported relative to VSMOW.

$\mathrm{Sr}$ isotopic ratios were measured on a Fisons-VGMicromass 54-30 Sector multicollector mass spectrometer. $\mathrm{Sr}$ was loaded in $1 \mathrm{~N} \mathrm{HNO}_{3}$ on a Ta single filament. $\mathrm{Sr}$ isotopic ratios were corrected for mass discrimination using ${ }^{86} \mathrm{Sr} /{ }^{88} \mathrm{Sr}=0,1194$. Replicate analyses of separate loads of NBS-987 yielded a mean ${ }^{87} \mathrm{Sr} /{ }^{86} \mathrm{Sr}=0,710250 \pm 0,000010$ (2Ф). $\mathrm{Rb}-\mathrm{Sr}$ isotope ratio was determined using an inductively coupled plasma mass spectrometry (ICP-MS). Detailed information on analytical procedures for ICP-MS analyses is given in Niu and Batiza (1997). The two sigma errors for the ${ }^{87} \mathrm{Rb} /{ }^{86} \mathrm{Sr}$ ratio were estimated at $2 \%$, and that of the ${ }^{87} \mathrm{Sr} /{ }^{86} \mathrm{Sr}$ ratio was estimated at $\pm 0.05 \%$. $\mathrm{Rb}-\mathrm{Sr}$ isochron ages were calculated using the Isoplot code of Ludwig (1996).

\section{Tectonic and Geological Setting}

The study area is located at the intersection between eastern part of izmir-Balıkesir Transfer Zone (IBTZ) and western end of Simav Graben (Figure 1). The Simav Graben is regarded as one of the latest product of $\mathrm{N}$-S extentional tectonics which affected the Eagean region in the Latest Oligocene-Early Miocene times (Seyitoğlu, 1997). On the other hand IBTZ is a transform fault in the Late-Cretaceous and acted as a transfer fault zone during Neogene (Okay and Siyako, 1991). IBTZ is intermittently reactivated since Miocene and present day reactivitation is also suggested (Özkaymak and Sözbilir, 2008; Uzel and Sözbilir, 2008). The autors are also determined that NE trending transfer zone includes NE-SW and NW-SE strike-slip and E-W striking normal faults which developed synchronously and are sysmically active. 


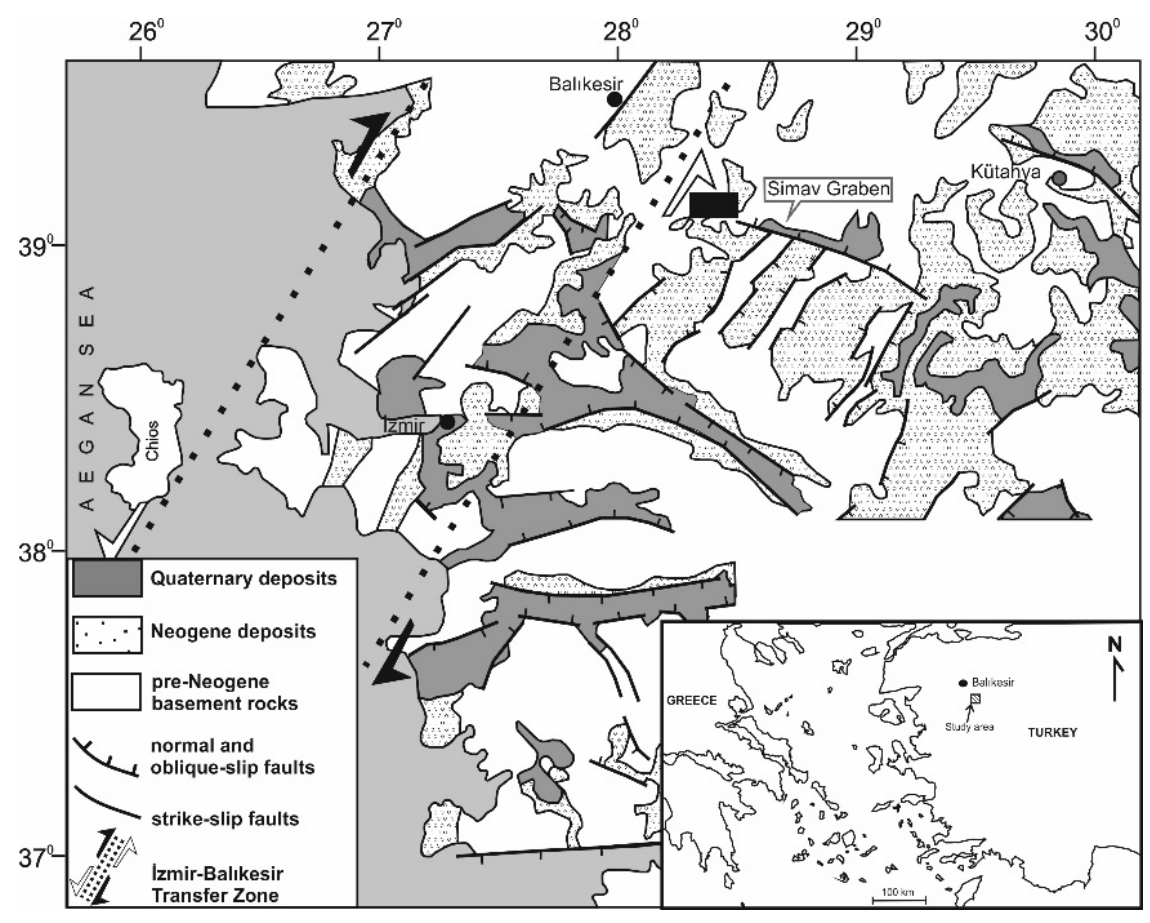

Figure 1. Simplified tectonic map of Western Anatolia showing Neogene/Quaternary basins and location of IBTZ (modified from Bozkurt, 2001). The black box represents the location of the study area.

Simav region at the west of the study area is characterized by extentional basins and hosts Early to Middle Miocene magmatic rocks (Çoban et al. 2012). Sindirgı volcanites involving the volcanics in the study area represents the begining of the Early Miocene extension (Erkul et al. 2005).

The basement rocks of the study area comprise of limestone olistoliths and ophiolitic rocks of the Bornova Flysch Zone (Okay and Siyako, 1991). The basement rocks are uncomformably overlain by Miocene volcanic series. These volcanic rocks are referred as Sindirgı volcanics which is a part of Bigadiç volcano-sedimentary succession (Helvacı, 1995; Erkul et al. 2005). Sındırgı volcanics consist of dacitic to rhyolitic intrusions, lava flows and pyroclastic rocks. The age of the Sindırgı volcanites are Early Miocene $20.2 \pm 0.5 \mathrm{Ma}$ for rhyolitic and $19.0 \pm 0.4 \mathrm{Ma}$ for dacitic rocks according to $\mathrm{K} / \mathrm{Ar}$ ages (Erkul at al., 2005).

The volcanic rocks in the study area are described as ignimbrite (Yılmaz et al. 2013). Ignimbrites are seperated into two units as lower and upper ignimbrite (Figure 2). Lower ignimbrite is a crystal rich unit and consists of K-feldspar, plagioclase, biotite, amphibole and rare pyroxene. The Lower ignimbrite is overlain by upper ignimbrite unit which is a pumice rich pyroclastic flow deposit. The ${ }^{40} \mathrm{Ar} /{ }^{39} \mathrm{Ar}$ age of the lower ignimbrite unit is $19.82 \pm 0.14 \mathrm{Ma}$. and the upper ignimbrite unit is $18.96 \pm 0.11 \mathrm{Ma}$ (Yılmaz et al. 2013).

The thermal waters are discharged along the intersection between the Simav Graben and the NE trending strike slip faults. The water, altered rock samples and HS-2 drillhole location are given in Figure 3. 


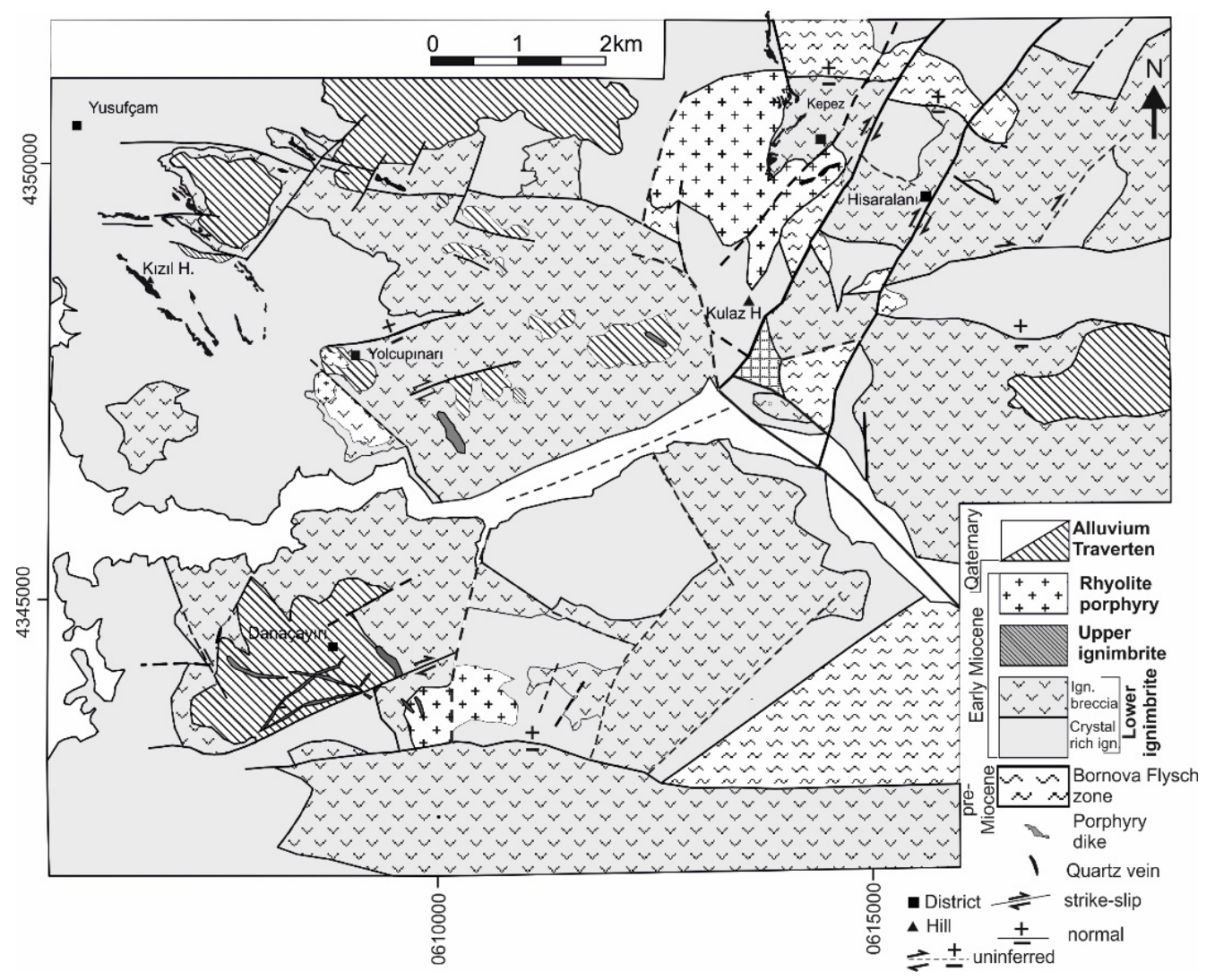

Figure 2. Geological map of the study area (Modified from Yilmaz et al. 2013).
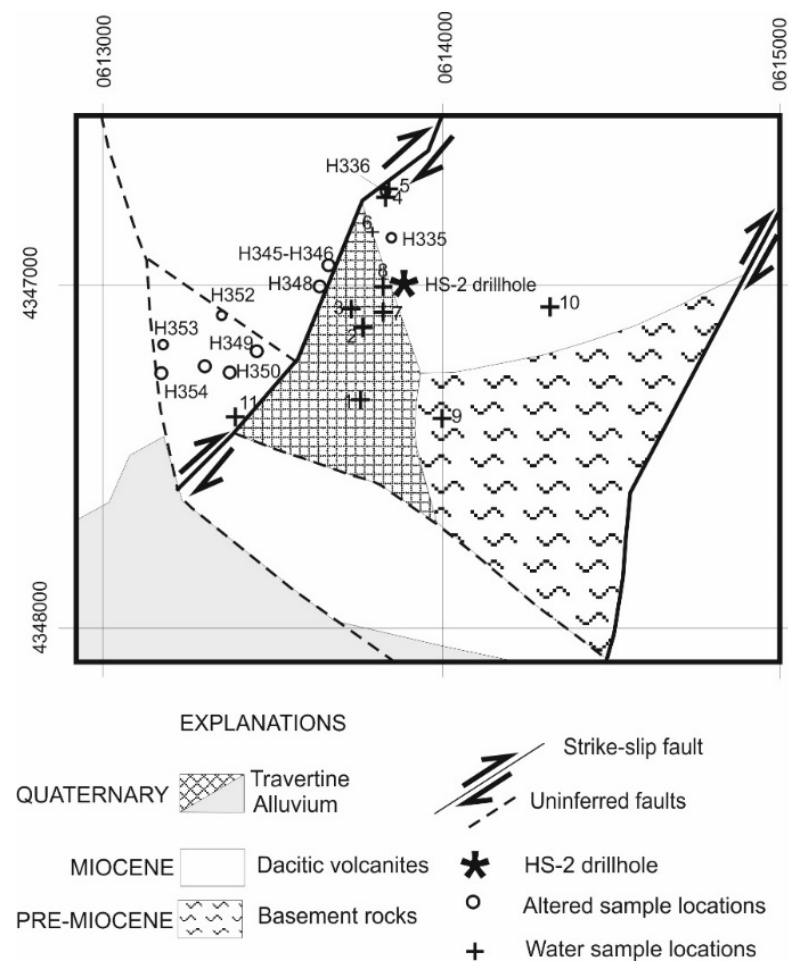

Figure 3. Sample location map of the Hisaralan geothermal field.

\section{RESULTS}

\subsection{Mineralogy}

\subsubsection{Optical Microscopy}

The petrographic studies show that the fossil hydrothermal alteration in the Hisaralan geothermal field has developed at two stages. The chloritization and carbonatization is the first stage and are followed by sericitic alteration and silisification at the second stage. The sericite crosscutting chlorite indicates that chlorite is postdated by sericite (Figure $4 a, b)$. The sericitization and chloritization of the matrix is common (Figure $4 c, d)$. Pyrite is probably formed by the excess Fe outcome of alteration of chlorite under reducing conditions (Figure 4e,f). The petrographic studies show that the common alteration in the Hisaralan geothermal field is sericitization of feldspar in lower ignimbrite unit. The plagioclases are altered to sericite (Figure 4g). Carbonatization accompanied to sericitization is observed (Figure 4f). 


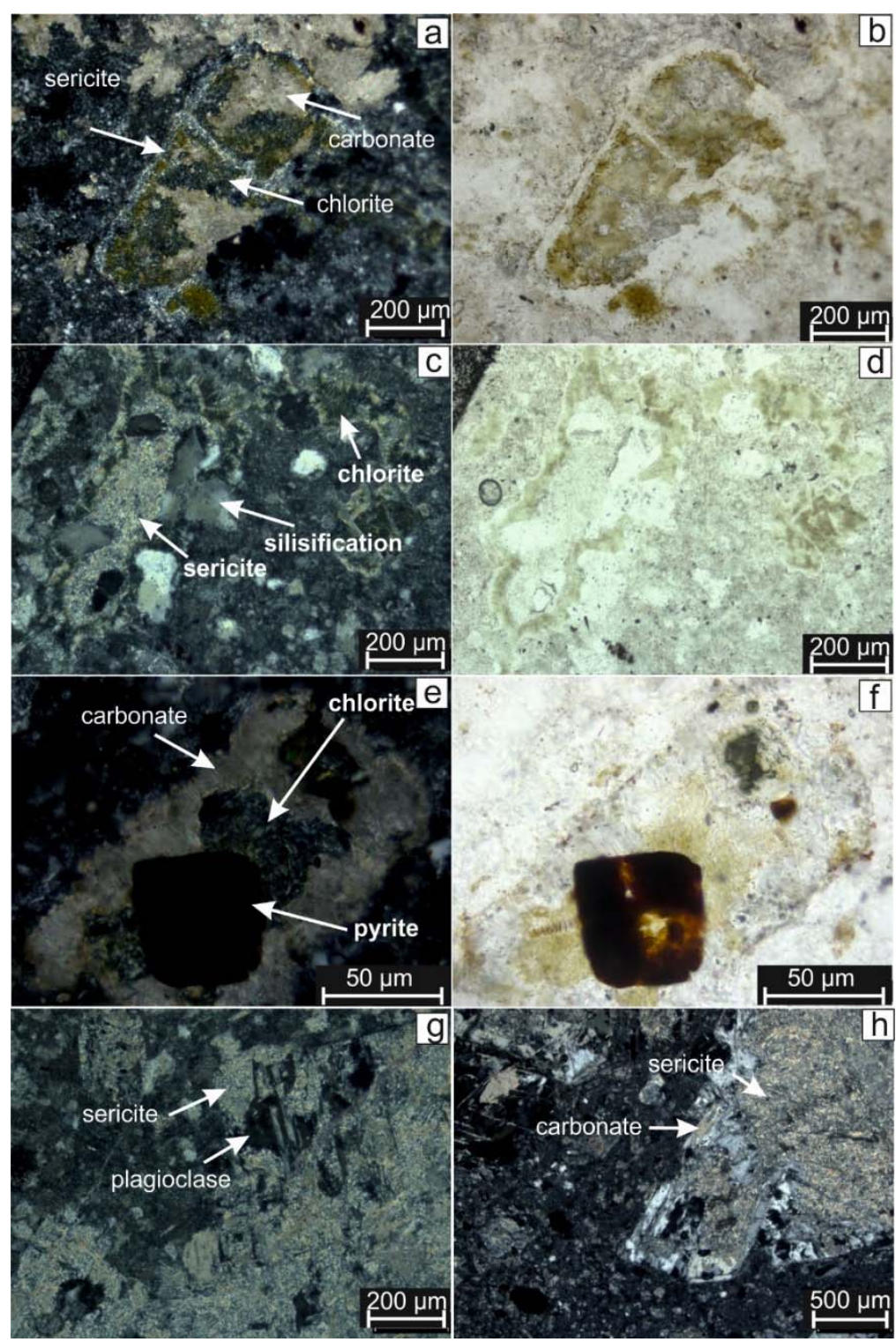

Figure 4. Photomicrographs: a) Chlorite, carbonate and sericite alteration probably formed from a feldspar; cross nicols $(\mathrm{H} 345)$, b) Paralel nicols of the previous view, c) Silisification, sericite and chlorite in the matrix of H16, d) Paralel nicols of the previous view, e) Chlorite and carbonate indicative of propylitic alteration. Pyrite crystallised probably from the remainning Fe. f) Paralel nicols of the previous view. g) Sericitization of plagioclase; cross nicols (Sample H16), h) carbonate alteration of feldspar and sericitization of plagioclase, cross nicols (Sample OR32).

\subsection{Clay mineralogy of HS-2 drillhole and outcrop samples}

Clay mineralogy of the drillhole samples were examined down to $464 \mathrm{~m}$ because volcanic sequence passes to the basement rocks below this level. XRD patterns of ethylene glycolated clay fractions $(<2 \mu \mathrm{m})$ of the HS-2 drillhole samples are given in Figure 5 and out crop samples in Figure 6. HS-2 drillhole samples include illite and/or I-S, chlorite and smectite while outcrop samples include kaolinite and halloysite as well. Random to $\mathrm{R} 1$ ordered I-S occurres in samples containing 60$70 \%$ illite layers and the full R2 ordering appears in I-S containing $>75 \%$ illite layers while R3 ordering occurres for $>85 \%$ illite layers (Bethke et al. 1986). In addition, an increase in the degree of ordering with increasing illite layers is referred for $1-S$ as follows; $R=0, R=1$ and $R>3$ ordering (Nadeau and Reynolds, 1981). If a reflection occurres between 
$5.3^{\circ}$ and $8.7^{\circ} 2 \theta$ the interstratifications is ordered (Srodon, 1980). All the samples including I-S display ordered interstratification in HS-2 drillhole and outcrop samples. Reichweite ordering and the proportion of smectite within I-S is determined by plotting the angular differences $\Delta 2 \theta_{2}\left(5,1-7,6^{\circ} 2 \theta\right.$ and $\left.8,9-10,2^{\circ} 2 \theta\right)$ and $\Delta 2 \theta_{1}\left(16,1-17,2^{\circ} 2 \theta\right.$ and 8,9 $\left.10,2^{\circ} 2 \theta\right)$ which are sensitive to variation of ordering (Watanabe, 1981; Inoue and Utada, 1983). Drillhole samples $36 \mathrm{~m}$ and $48 \mathrm{~m}$ and outcrop samples H345, H348 and KU contain R2 I-S (Figure 7a). The degree of ordering is determined by the diagram displaying the relationship between $\Delta 2 \theta_{1}$ and smectite content (\%) of I-S (Srodon, 1980). The samples 36m, 48m, H345, H348 and KU are ISII ordered I-S (Figure 7b).The samples from 190 to 464 are R3 I-S according to the $\Delta 2 \theta$ estimation for identification Reichweite (Moore and Reynolds, 1997; Table 1).

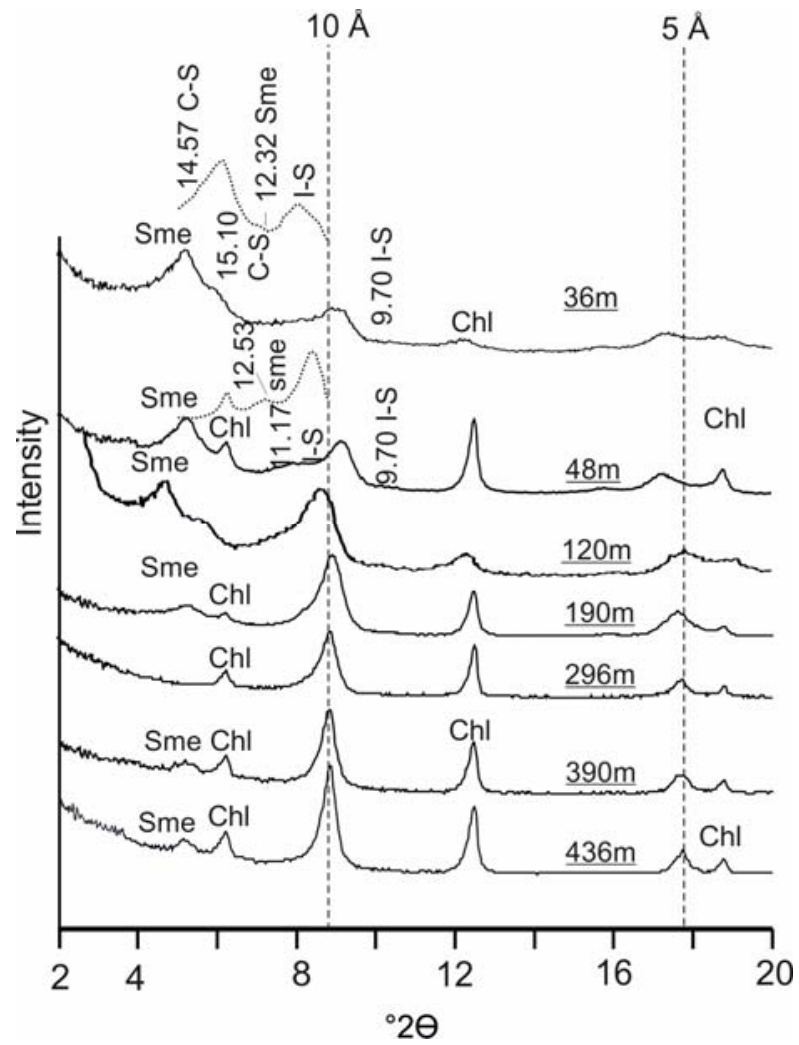

Figure 5. XRD pattern of $<2 \mu \mathrm{m}$ clay fraction of ethylene glycolated HS-2 drillhole samples. The dashed lines represent air dried pattern. Sme: smectite, Chl: chlorite, I$\mathrm{S}$ : Mixed layered illite-smectite. The numbers above the peaks indicate $d$ spacings $(\AA)$.

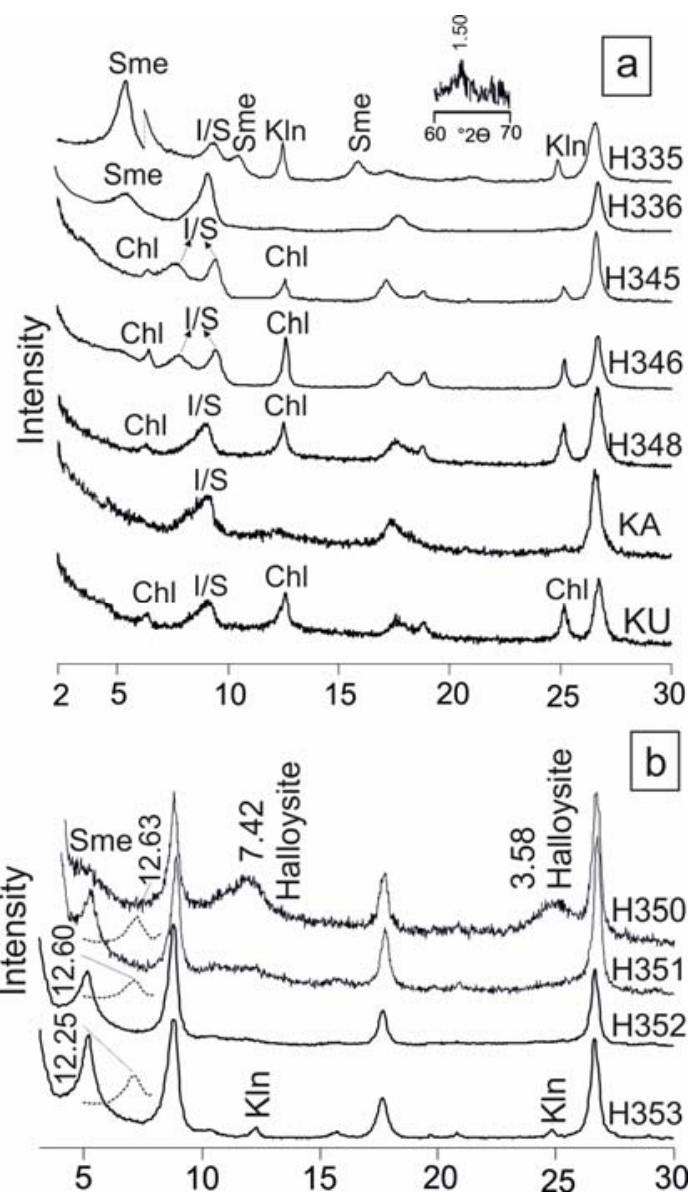

Figure 6. XRD pattern of $<2 \mu \mathrm{m}$ clay fraction of ethylene glycolated outcrop samples. The dashed lines represent aird dried pattern of smectite. Sme: smectite, I-S: illitesmectite mixed layers, Kln: kaolen, Chl: chlorite.

Table 1. XRD data for illite and/or I-S mixed layer for HS-2 drillhole and outcrop sample.

\begin{tabular}{|c|c|c|c|c|}
\hline Sample & $\begin{array}{c}\text { \%illite layers } \\
\text { in I-S }\end{array}$ & Reichweite & Ir & Type of illite \\
\hline \multicolumn{5}{|c|}{ HS-2 drillhole samples } \\
\hline $36 \mathrm{~m}$ & $85-90 \%$ & 8.19 & - & R2 I-S \\
\hline $48 m$ & $80-85 \%$ & 8.08 & - & R2 I-S \\
\hline $120 m$ & $90-95 \%$ & 7.72 & - & R3 I-S \\
\hline $190 m$ & $>95 \%$ & 8.75 & - & R3 I-S \\
\hline $254 m$ & - & 8.87 & 2.07 & I and/or I-S \\
\hline $296 m$ & - & 8.91 & 1.25 & I and/or I-S \\
\hline $390 m$ & - & 8.90 & 1.39 & I and/or I-S \\
\hline $436 m$ & - & 8.89 & 1.26 & I and/or I-S \\
\hline $464 m$ & - & 8.83 & 1 & Illite \\
\hline \multicolumn{5}{|c|}{ Outcrop samples } \\
\hline H335 & $80 \%$ & 7.91 & - & R2 I-S \\
\hline H336 & $95-100 \%$ & 8.63 & - & R3 I-S \\
\hline H345 & $80 \%$ & 7.84 & - & R2 I-S \\
\hline H346 & $80 \%$ & & & R2 I-S \\
\hline H348 & $85-90 \%$ & 8.08 & - & R3 I-S \\
\hline H349 & - & - & - & I and/or I-S \\
\hline H350 & - & - & - & I and/or I-S \\
\hline H351 & - & - & 1.58 & I and/or I-S \\
\hline H352 & - & - & 1.25 & I and/or I-S \\
\hline H353 & - & - & 1.36 & I and/or I-S \\
\hline $\mathrm{KA}$ & $\sim 10 \%$ & 8.53 & - & R3 I-S \\
\hline KU & $85-90 \%$ & 8.34 & - & R3 I-S \\
\hline
\end{tabular}


The $d_{001}$ values of smectites between 14.89 to $15.28 \AA$ indicates Ca-smectite while the $d_{001}$ values are between 12-12.5 ̊ indicates Na-smectite (Brown and Brindley, 1980). The basal spacings of 12.32 and $12.53 \AA$ of air-dried XRD patterns for $36 \mathrm{~m}$ and $48 \mathrm{~m}$ indicates Na-smectite (Figure 5). The peaks shift toward $\sim 17 \AA$ after ethylene glycol saturation. The $d_{060}$ at near 1.50 reveals dioctahedral character of smectite. The chlorite is determined by the reflections at 001, 002, 003 and 004 and the peaks belong to these reflections are $\sim 14.20 \AA, \sim 7.10 \AA, \sim 4.72 \AA$ and $\sim 3.54 \AA$ respectively (Moore and Reynolds, 1997; Figure 5).

The surface samples collected inside and around the geothermal field contains smectite, I-S and chlorite (Figure 6a, b). Smectite is the dominant clay mineral in sample $\mathrm{H} 335$ and $d_{060}$ at near 1.50 $\AA$ reveals dioctahedral character. The samples H350, H351, H352, H353 are also contain Nasmectite (Figure 6b). The distinction between kaolinite and chlorite is determined by the peak at $3.58 \AA$ for kaolinite and $3.54 \AA$ for chlorite. H335, H345 and H346 consists of R2 I-S while H336, KA, $\mathrm{KU}$ and H349 to H353 include R3 I-S (Table 1). In additon $\mathrm{H} 335$ includes kaolin mineral (probably kaolinite) determined by the $7.17 \AA$ and $3.58 \AA$ peaks. Halloysite is determined in $\mathrm{H} 350$ by the $7.42 \AA$ and $3.58 \AA$ peaks (Figure 6b). The halloysite is also supported by SEM analysis.

The smectite content of I-S is the highest (20\%) for samples H345 and H346 (Figure 8). The samples H349 to H353 has both discrete illite and I-S because they fall the illite field on the diagram of Srodon (1980) and is shown in Figure 8. The Ir values are higher than 1 (Table 1 ).

The illite and/or I-S were plotted (002) versus (003) reflections on the diagram (Figure 8; Srodon, 1984). The samples below the illite field are regarded as pure I-S mixed layer minerals. The samples in the illite field are discrete illite or a mixture of illite and I-S mixed layers. Then the intensity ratio
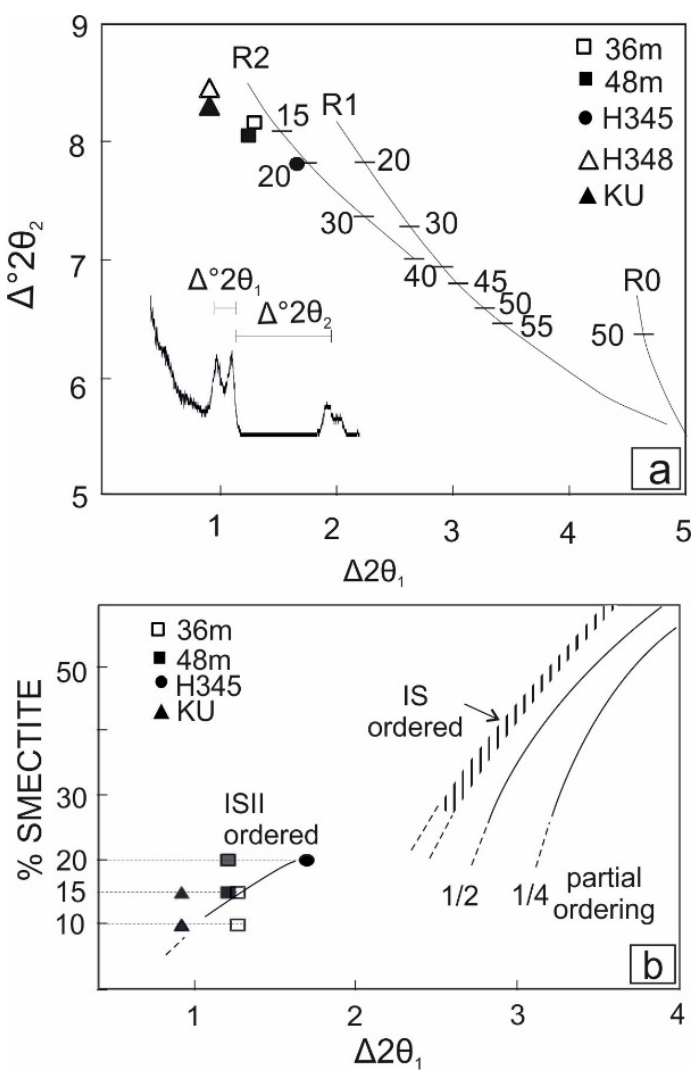

Figure 7. a) Diagram displaying $\Delta 2 \theta_{1}$ versus $\Delta 2 \theta_{2}$ for determining Reichweite ordering and the proportion of smectite within I-S (Watanabe, 1981; Inoue and Utada, $1983)$, b) Plot of $\Delta 2 \theta_{1}$ versus proportion of smectite of I-S for estimation degree of ordering (Srodon, 1980).

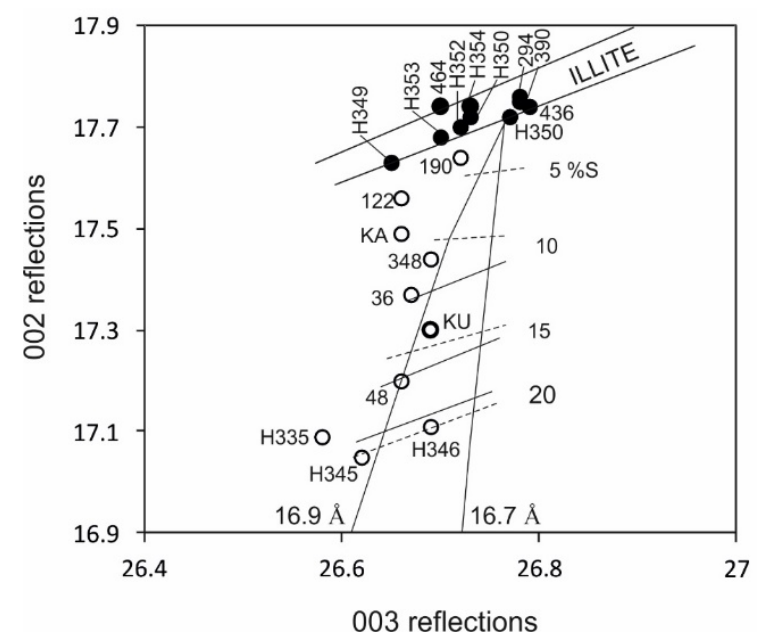

Figure 8. Plot of 002 and 003 reflections of I-S and/or illite for HS-2 drillhole and outcrop samples. Solid lines: IS type ordering Dashed lines: ISII type ordering (Srodon, 1984). 
(Ir) can be checked for these samples to identify amount of expandable material (Srodon, 1984). The peak heights ratio of 001 and 003 reflections from air-dried and ethylene glycolated samples represents intensity ratio (Ir). Ir=1 indicates the sample consists of discrete illite while the Ir $>1$ means sample is a mixture of discrete illite and IS.

The drillhole samples $36 \mathrm{~m}, 48 \mathrm{~m}, 122 \mathrm{~m}$ and $190 \mathrm{~m}$ are pure I-S lacking discrete illite because the samples are below the illite field (Figure 8). The $294 \mathrm{~m}$ and $436 \mathrm{~m}$ have both illite and I-S. The deepest sample of the well $464 \mathrm{~m}$ has (Ir) value equal to 1 and contain discrete illite lacking I-S (Table 1). The amount smectite component of I-S and Ir values are given in Table 1.

\subsection{SEM studies}

Chlorite is characterized by thin stacks, pseudohexagonal and lath shaped plates with 5$10 \mu \mathrm{m}$ crystal thickness (Figure 9a). The SEM image to the left upper side of the Figure 9a consists completely of random oriented thin plates of chlorite. Chemical analyses by EDS determines the chlorite is iron rich (Table 2). Vermicular form of chlorite is also observed by SEM analysis and is probably formed by transformation of amphibole determined also by petrographic analysis. Chlorite crystals covered by I-S indicates chlorite was formed earlier than illitic minerals (illite/or I-S) (Figure 9c). The sample from drillhole $328 \mathrm{~m}$ displays somewhat curved and lath shape morphology (Figure 9d). Lath shaped coarse crystals are characteristic for illite rich I-S. The EDS analyses from the morphology for highly illite bearing I-S minerals were reported by SEM and TEM studies (Keller, 1986; Inoue et al. 1987). On the other hand, highly expandable I-S with $\sim 20 \%$ illite layers displays a honeycomb morphology (Figure 9e and 9f). In addition, the $\mathrm{K}_{2} \mathrm{O}$ contents of $328 \mathrm{~m}$ (drillhole sample) is higher than H345 and H335. There is no evidence for a transition or an over growth in these morphology as suggested by Pollastro (1985). It is concluded that illite is formed by direct precipitation and it is not formed by smectite to illite transformation. Morphology of illitic minerals changes with increasing illite content.

Kaolin minerals transformed to I-S indicates that kaolinite formation belongs to a past hydrothermal system probably related to epithermal veins which can be found nearby geothermal field (Figure 10a). Rosetta shape hematite is determined in sample H345 (Figure 10b). The occurrence of hematite on the surface of clay minerals may indicate late phase and probably present day precipitation from geothermal fluids. Halloysite is determined in the fissures of the surface samples H350 (Figure 10c). The spiral tube shaped morphology of halloysite in H336 is given in the magnified SEM image (Figure 10d). This kind of halloysite formations are precipitated from low temperature weathering profiles (Papoulis et al. 2004; Ece and Schroeder, 2007). 


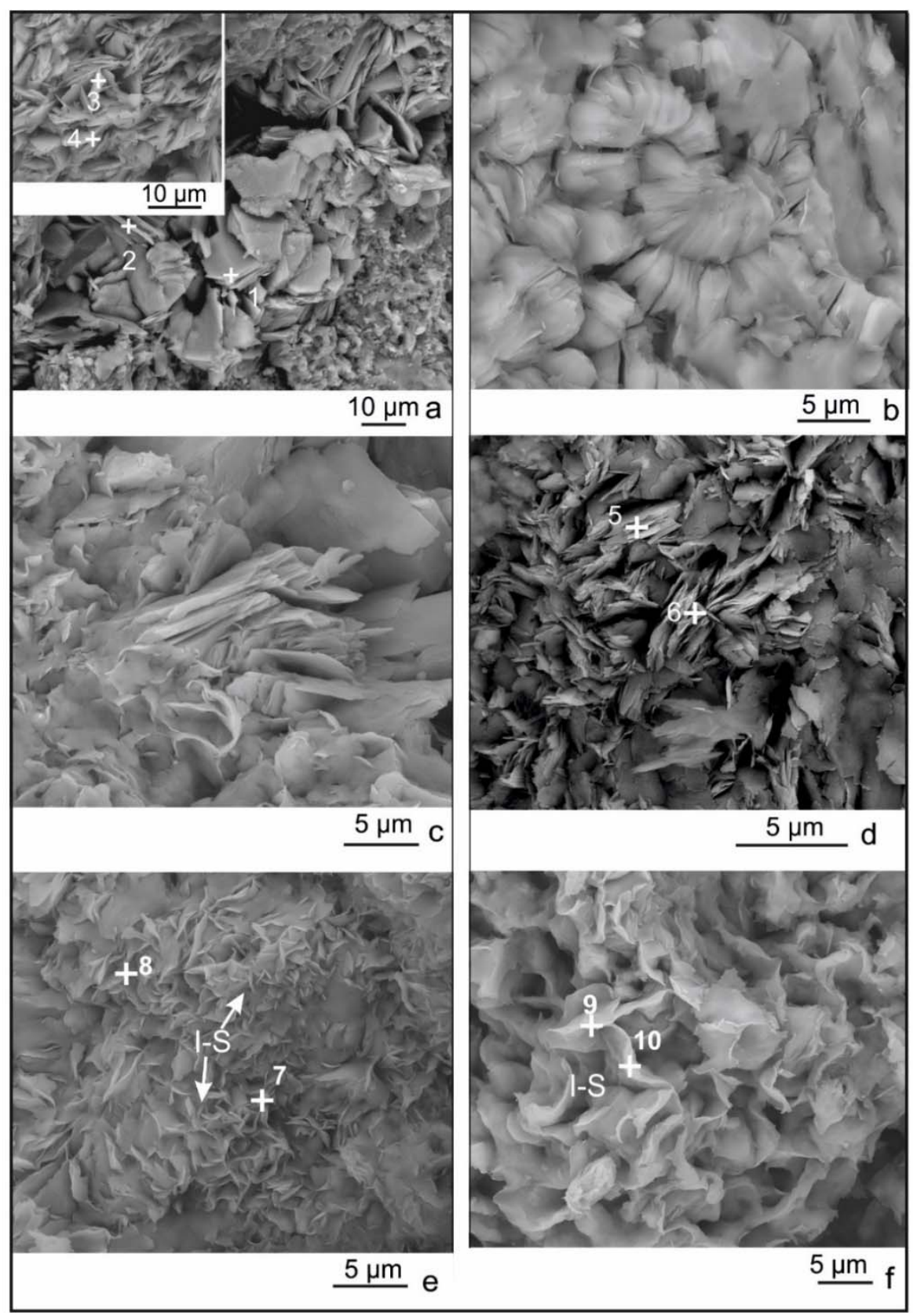

Figure 9. a) Pseudohexagonal chlorite crystals (H346) and randomly oriented chlorite crystals (upper left image), b) Vermicular form of chlorite (H345), c) Chlorite crystals covered by I-S (H345), d) Lath shaped > $5 \mu$ m subhedral crystals of I-S from drilling (sample 328), e) Highly expandable I-S displaying honeycomb morphology from sample H345, and f) H335. The numbers represent EDS analyses points.

Table 2: EDS analyses of mixed layer clay minerals (I-S) and chlorite (chl).

\begin{tabular}{lcccccccccc}
\hline $\begin{array}{l}\text { EDS } \\
\text { points }\end{array}$ & $\begin{array}{c}\mathbf{1} \\
\text { chl }\end{array}$ & $\begin{array}{c}\mathbf{2} \\
\text { chl }\end{array}$ & $\begin{array}{c}\mathbf{3} \\
\text { chl }\end{array}$ & $\begin{array}{c}\mathbf{4} \\
\text { chl }\end{array}$ & $\begin{array}{c}\mathbf{7} \\
\mathbf{1 - S}\end{array}$ & $\begin{array}{c}\mathbf{8} \\
\mathbf{1 - S}\end{array}$ & $\begin{array}{c}\mathbf{5} \\
\mathbf{1 - S}\end{array}$ & $\begin{array}{c}\mathbf{6} \\
\mathbf{1 - S}\end{array}$ & $\begin{array}{c}\mathbf{9} \\
\mathbf{I - S}\end{array}$ & $\begin{array}{c}\mathbf{1 0} \\
\mathbf{1 - S}\end{array}$ \\
\hline Sample & $\mathbf{H 3 4 6}$ & $\mathbf{H 3 4 6}$ & $\mathbf{H 3 4 5}$ & $\mathbf{H 3 4 5}$ & $\mathbf{H 3 4 5}$ & $\mathbf{H 3 4 5}$ & $\mathbf{H 3 2 8}$ & $\mathbf{H 3 2 8}$ & $\mathbf{H 3 3 5}$ & $\mathbf{H 3 3 5}$ \\
\hline $\mathrm{SiO}_{2}$ & 36.65 & 35.04 & 39.38 & 36.29 & 55.23 & 54.78 & 50.59 & 51.63 & 59.62 & 58.68 \\
$\mathrm{Al}_{2} \mathrm{O}_{3}$ & 24.96 & 24.88 & 21.81 & 23.97 & 32.35 & 33.08 & 32.25 & 32.41 & 26.51 & 28.17 \\
$\mathrm{FeO}$ & 25.90 & 28.61 & 25.87 & 22.27 & 1.90 & 2.01 & 3.67 & 3.44 & 4.19 & 3.03 \\
$\mathrm{MgO}$ & 11.09 & 10.33 & 9.82 & 14.42 & 1.30 & 1.46 & 3.79 & 3.02 & 2.29 & 2.03 \\
$\mathrm{CaO}$ & 0.68 & 0.45 & 1.50 & 0.87 & 0.74 & 1.03 & 0.48 & - & 0.23 & 0.33 \\
$\mathrm{Na}_{2} \mathrm{O}$ & 0.38 & 0.68 & 0.12 & 0.41 & 0.18 & 0.18 & 0.28 & - & 1.33 & 1.31 \\
$\mathrm{~K}_{2} \mathrm{O}$ & 0.34 & - & 1.51 & 1.26 & 8.30 & 7.48 & 8.93 & 9.51 & 5.01 & 5.16 \\
$\mathrm{TiO}_{2}$ & - & - & - & - & - & - & - & - & 0.83 & 1.30 \\
\hline
\end{tabular}




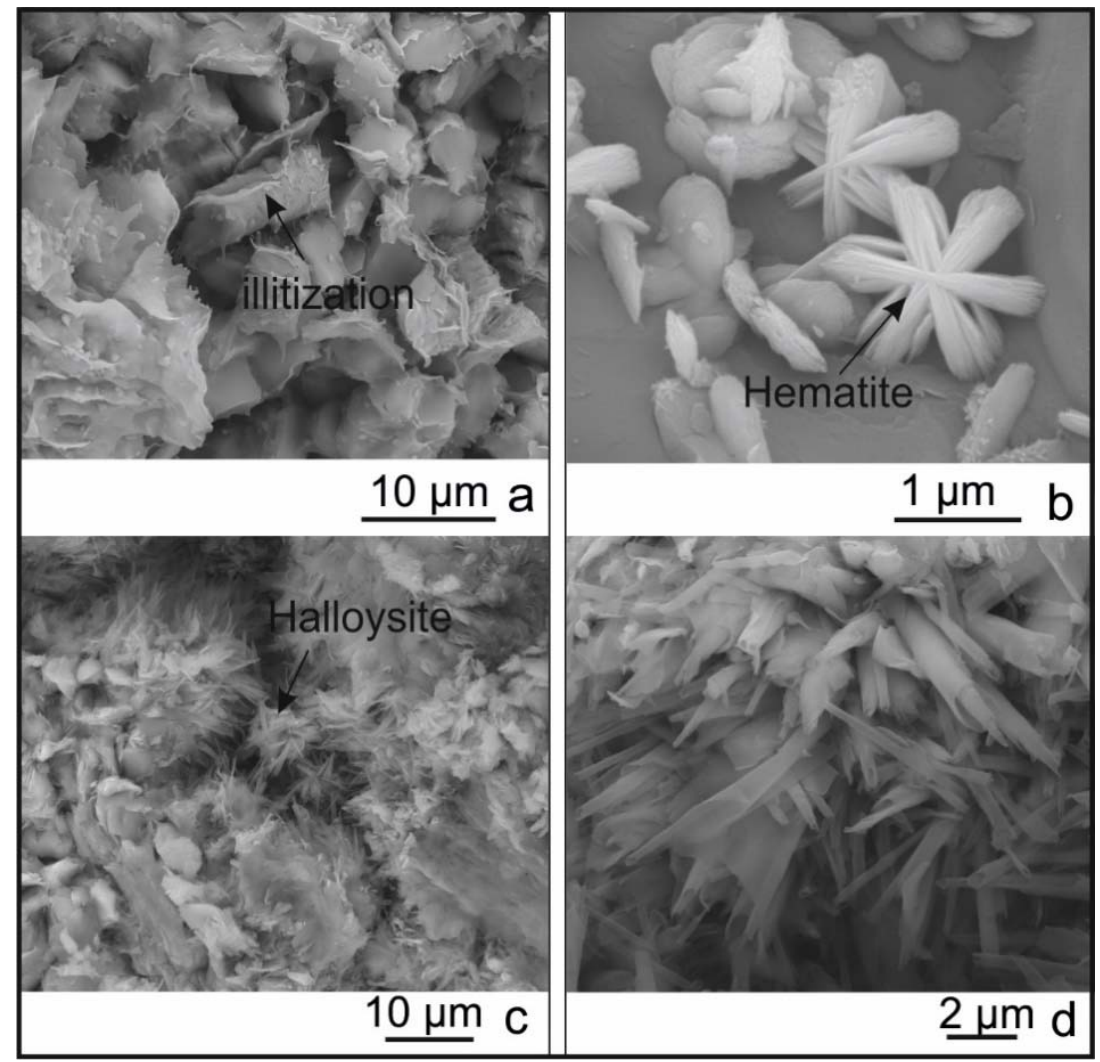

Figure 10. a) Transformation of kaolen minerals into I-S in sample H335; (b) Rosetta shaped hematite crystal on the sample surface; (c) Halloysite crystals in the voids of fissures (H350) and (d) Spiral tube shaped structure of halloysite (H336).

\section{Geochemistry}

The major and trace element contents of fresh rock (KU19) and altered rocks are given in Table 3. The chemical index of alteration and mobilization of elements during alteration is discussed.

\subsection{Chemical indices}

An alternative index of chemical weathering derived from unweathered igneous rocks and their weathering profiles is used. MFW ternary diagram determines the extent of alteration and composition of the parent rock (Ohta and Arai, 2007). The $M$ and $F$ vertices characterize mafic and felsic rock sources while $W$ determines the degree of weathering. An increase in the $W$ value is an indication of increase in the abundance of phyllosilicates. A combined diagram of $\mathrm{A}-\mathrm{CN}-\mathrm{K}$ and $\mathrm{CIA}$ classifying the alteration intensity is used (Shao et al. 2012). The samples are also controlled with respect to loss on Ignition (LOI). The formulas for weathering indices are given in Table 4. The samples KU19, 390m, 464m fall on the igneous trend and have dacitic to andesitic composition Figure 11a. These samples are very close to a value 50 for $\mathrm{CIA}$ and displays no weathering according to the $\mathrm{A}-\mathrm{CN}-\mathrm{K}$ diagram (Figure $11 \mathrm{~b}$ ). $464 \mathrm{~m}$ is observed as the least altered sample among the others with close to $40 \mathrm{CIA}$ value, but it can not be a fresh rock with a high LOI value. The lowest LOI value belongs to the KU19 so the sample was chosen for normalization calculations. None of the altered samples in Hisaralan geothermal field display strong weathering (Figure 11b). The drillhole samples fall into weak weathering field while outcrop samples fall into the intermediate weathering. 
Table 3. Major (wt. \%) and trace element (in ppm)analysis of fresh and altered samples in Hisaralan geothermal field.

\begin{tabular}{|c|c|c|c|c|c|c|c|c|c|c|c|}
\hline & 36 & 190 & 294 & 390 & H349 & H350 & H345 & H335 & H336 & H353 & KU19 \\
\hline \multicolumn{12}{|c|}{ Major element contents (wt. \%) } \\
\hline $\mathrm{SiO}_{2}$ & 65.61 & 65.71 & 71.70 & 63.90 & 71.25 & 69.60 & 62.37 & 75.77 & 71.45 & 72.26 & 63.54 \\
\hline $\mathrm{Al}_{2} \mathrm{O}_{3}$ & 11.39 & 12.07 & 11.26 & 14.27 & 15.51 & 17.08 & 14.87 & 12.79 & 15.30 & 16.12 & 16 \\
\hline $\mathrm{Fe}_{2} \mathrm{O}_{3}$ & 5.47 & 4.68 & 4.44 & 4.08 & 2.30 & 1.60 & 3.74 & 1.78 & 2.14 & 1.19 & 4.16 \\
\hline MgO & 1.90 & 1.60 & 1.53 & 1.72 & 0.97 & 0.54 & 2.26 & 0.99 & 0.72 & 0.69 & 1.73 \\
\hline $\mathrm{CaO}$ & 4.81 & 5.05 & 2.60 & 4.23 & 0.23 & 0.17 & 4.74 & 0.27 & 0.13 & 0.08 & 4.20 \\
\hline $\mathrm{Na}_{2} \mathrm{O}$ & 0.16 & 0.74 & 0.07 & 2.06 & 0.26 & 1.12 & 0.12 & 0.52 & 0.18 & 0.99 & 2.70 \\
\hline $\mathrm{K}_{2} \mathrm{O}$ & 2.25 & 2.43 & 2.99 & 2.83 & 4.01 & 3.75 & 2.60 & 2.46 & 3.97 & 3.91 & 2.89 \\
\hline $\mathrm{TiO}_{2}$ & 0.54 & 0.52 & 0.54 & 0.55 & 0.59 & 0.61 & 0.59 & 0.57 & 0.57 & 0.68 & 0.60 \\
\hline $\mathrm{P}_{2} \mathrm{O}_{5}$ & 0.13 & 0.14 & 0.16 & 0.16 & 0.02 & 0.05 & 0.14 & 0.09 & 0.12 & 0.02 & 0.15 \\
\hline LOI & 7.5 & 6.8 & 4.5 & 5.9 & 4.7 & 5.3 & 8.3 & 4.6 & 5.2 & 3.9 & 3.6 \\
\hline Sum & 99.87 & 99.84 & 99.87 & 99.78 & 99.80 & 99.85 & 99.80 & 99.86 & 99.79 & 99.87 & 99.65 \\
\hline TOT/C & 0.9 & 1.1 & 0.5 & 0.9 & 0.1 & 0.0 & 0.9 & 0.1 & 0.1 & 0.0 & 0.4 \\
\hline TOT/S & 1.6 & 0.9 & 1.2 & 1.0 & 0.0 & 0.0 & 0.0 & 0.0 & 0.2 & 0.0 & 0.0 \\
\hline \multicolumn{12}{|c|}{ Trace element contents (ppm) } \\
\hline $\mathrm{Ba}$ & 445 & 573 & 346 & 873 & 760 & 692 & 667 & 509 & 840 & 268 & 1224 \\
\hline $\mathrm{Be}$ & 2 & 2 & 3 & 5 & 2 & 1 & 2 & 3 & 2 & 2 & 3 \\
\hline Co & 9.8 & 7.2 & 6.3 & 7.3 & 6.9 & 3.9 & 16.8 & 3.3 & 10.8 & 6.8 & 32.9 \\
\hline Cs & 9.1 & 8.7 & 7.8 & 8.9 & 23.1 & 16.1 & 4.4 & 33.9 & 19.2 & 19.7 & 7.3 \\
\hline Ga & 14 & 12.5 & 12.8 & 14 & 20.6 & 18.1 & 14.5 & 29.1 & 20.9 & 21.1 & 18.1 \\
\hline $\mathrm{Hf}$ & 4.5 & 4.5 & 4.5 & 5.9 & 5.3 & 5.3 & 4.9 & 3.5 & 5 & 5.2 & 5.5 \\
\hline Nb & 11.6 & 11.7 & 13.9 & 11.9 & 9.3 & 13.4 & 10.9 & 10.8 & 10.7 & 12.3 & 10 \\
\hline $\mathbf{R b}$ & 92.4 & 102.3 & 153.1 & 126.7 & 193.0 & 181.2 & 97.3 & 113.6 & 166.5 & 223.1 & 97.3 \\
\hline Sc & 10 & 9 & 9 & 10 & 13 & 10 & 13 & 10 & 12 & 13 & 13 \\
\hline Sn & 2 & 2 & 3 & 3 & 2 & 3 & 2 & 1 & 4 & 3 & 3 \\
\hline $\mathrm{Sr}$ & 90.8 & 126.0 & 56.7 & 236.6 & 44.4 & 144.7 & 131.4 & 207.5 & 57.5 & 67.3 & 475.2 \\
\hline Ta & 0.9 & 1 & 0.7 & 0.8 & 0.8 & 0.8 & 0.8 & 0.6 & 1.0 & 1.0 & 0.8 \\
\hline Th & 10.2 & 11.3 & 10.4 & 11.9 & 11.2 & 9.8 & 11 & 8.9 & 14.0 & 8.9 & 12.8 \\
\hline u & 2.2 & 4.5 & 3.5 & 3.9 & 4.3 & 3.7 & 2.4 & 2.8 & 4.3 & 4.1 & 3.7 \\
\hline v & 31 & 50 & 60 & 58 & 103 & 66 & 41 & 55 & 66 & 78 & 95 \\
\hline w & 14.3 & 4.8 & 5.5 & 4.7 & 50.3 & 41.5 & 38.6 & 44.9 & 123.9 & 81.4 & 248.7 \\
\hline $\mathrm{Zr}$ & 137.7 & 144.1 & 136.9 & 147.0 & 186.1 & 150.0 & 134.4 & 120.0 & 177.7 & 195.1 & 200.1 \\
\hline$Y$ & 23.3 & 24.8 & 24.3 & 25.6 & 16.3 & 12.1 & 22.1 & 10.7 & 17.3 & 12.6 & 25.5 \\
\hline
\end{tabular}

Table 4. Formulas for weathering indices.

\begin{tabular}{ll}
\hline Indice & Formula \\
\hline $\mathrm{ClA}$ & $\mathrm{Al}_{2} \mathrm{O}_{3} /\left(\mathrm{Al}_{2} \mathrm{O}_{3}+\mathrm{CaO}+\mathrm{Na}_{2} \mathrm{O}+\mathrm{K}_{2} \mathrm{O}\right) 100$ \\
$\mathrm{~A}-\mathrm{CN}-\mathrm{K}$ & $\left(\mathrm{Al}_{2} \mathrm{O}_{3}-\mathrm{CaO}\right)+\mathrm{Na}_{2} \mathrm{O}-\mathrm{K}_{2} \mathrm{O}$ \\
$M=0.395 \times \ln \left(\mathrm{SiO}_{2}\right)+0.206 \times \ln \left(\mathrm{TiO}_{2}\right) 0.316 \times \ln \left(\mathrm{Al}_{2} \mathrm{O}_{3}\right)+0.160 \times \ln \left(\mathrm{Fe}_{2} \mathrm{O}_{3}\right)+0.246 \times \ln (\mathrm{MgO})+0.368 \times \ln (\mathrm{CaO})+0.073 \times \ln \left(\mathrm{Na}{ }_{2} \mathrm{O}\right)-0.342 \times \ln \left(\mathrm{K}_{2} \mathrm{O}\right)+2.266$. \\
$F=0.191 \times \ln \left(\mathrm{SiO}_{2}\right)-0.397 \ln \left(\mathrm{TiO}_{2}\right)+0.020 \ln \left(\mathrm{Al}_{2} \mathrm{O}_{3}\right)-0.375 \times \ln \left(\mathrm{Fe}_{2} \mathrm{O}_{3}\right)-0.243 \ln (\mathrm{MgO})+0.079 \ln (\mathrm{CaO})+0.392 \times \ln \left(\mathrm{Na}_{2} \mathrm{O}\right)+0.333 \times \ln \left(\mathrm{K}_{2} \mathrm{O}\right)-0.892$ \\
$W=0.203 \times \ln \left(\mathrm{SiO}_{2}\right)+0.191 \times \ln \left(\mathrm{TiO}_{2}\right)+0.296 \times \ln \left(\mathrm{Al}_{2} \mathrm{O}_{3}\right)+0.215 \times \ln \left(\mathrm{Fe}_{2} \mathrm{O}_{3}\right)-0.002 \times \ln (\mathrm{MgO})-0.448 \times \ln (\mathrm{CaO})-0.464 \times \ln \left(\mathrm{Na}_{2} \mathrm{O}\right)+0.008 \times \ln \left(\mathrm{K}_{2} \mathrm{O}\right)-1.374$ \\
\hline
\end{tabular}

The immobile elements are determined by using binary plots of elements that show a linear trend passing from the origin and high correlation coefficient (MacLean and Kranidiotis, 1987). The $\mathrm{Sc}-\mathrm{Zr}$ and $\mathrm{Al}_{2} \mathrm{O}_{3}-\mathrm{Zr}$ gives the highest correlation coefficient 0.97 and 0.93 respectively (Table 5).
Binary plots of these elements display a linear trend passing from the origin and it is concluded that these elements are immobile (Figure 12). The sample H335 is extracted from the calculations because it's low $\mathrm{Zr}$ content which indicates a loss probably due to high alkali environment of surface conditions 


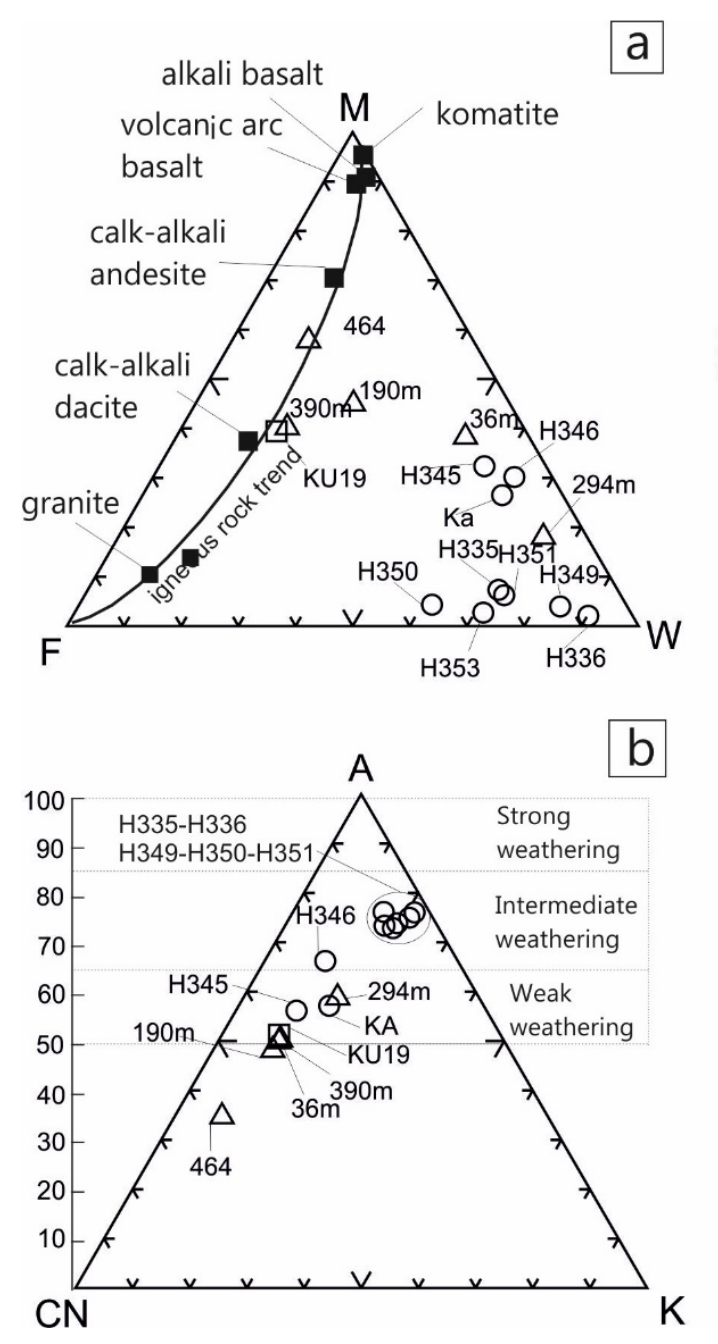

Figure 11. a) MFW diagram, black squares are taken from Ohta and Arai (2007), b) Combined A-CN-K and CIA diagram (Shao et al. 2012).

The $\mathrm{Al}_{2} \mathrm{O}_{3}$ is taken immobile for the comparison between the altered rocks and fresh rock. The element gains and losses were determined by normalized the $\mathrm{Al}_{2} \mathrm{O}_{3}$ content of altered samples to $\mathrm{Al}_{2} \mathrm{O}_{3}$ content of fresh rock (KU19). According to the normalized plots the samples enriched in $\mathrm{SiO}_{2}$ between $13-60 \%$ and enriched in $\mathrm{K}_{2} \mathrm{O}$ between $6-$ $47 \%$ (Figure 13). Small amount of enrichment in some of the samples considered to be immobile. $\mathrm{MgO}$ and $\mathrm{Fe}_{2} \mathrm{O}_{3}$ are enriched in chlorite bearing drillhole samples while they are lost in the chlorite deficient samples. The smectite rich samples H335 and $\mathrm{H} 336$ are also lost in $\mathrm{Fe}_{2} \mathrm{O}_{3}$ and $\mathrm{MgO}$ during alteration. The $\mathrm{Na}_{2} \mathrm{O}$ is lost in all the samples while $\mathrm{CaO}$ is lost in outcrop samples and is enriched in drillhole samples. Enrichment of $\mathrm{CaO}$ is probably due to the secondary calcite in drillhole samples which is also determined by XRD.
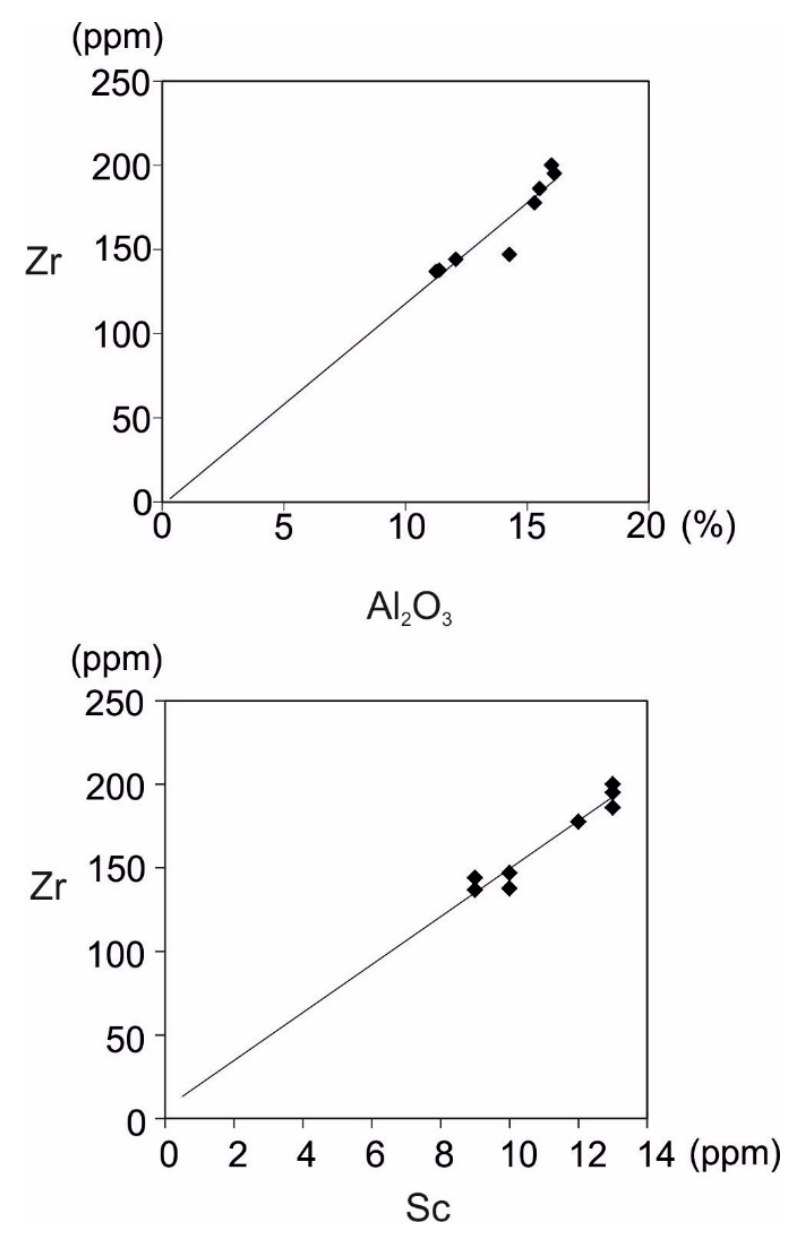

Figure 12. $\mathrm{Zr}-\mathrm{Al}_{2} \mathrm{O}_{3}$ and $\mathrm{Zr}-\mathrm{Sc}$ binary plots showing linear trends passing from the origin.

$\mathrm{Cs}$ and $\mathrm{Rb}$ are gained with $\mathrm{K}_{2} \mathrm{O}$. On the other hand, $\mathrm{Sr}$ is behaved as $\mathrm{CaO}$ and enriched (Figure 14). The immobile elements displays less than $21 \%$ variation. The variations are $21 \%$ for $\mathrm{Ga}, 20 \%$ for $\mathrm{Hf}, 14 \%$ for Sc and $17 \%$ for Th. On the other hand, Ga is two fold enriched and $\mathrm{Zr}$ is $25 \%$ lost in $\mathrm{H} 335$. Th is $31 \%$ lost in $\mathrm{H} 353$. Ta displays small enrichment in some of the samples. $Y$ is gained in drilhole samples while it is lost in outcrop samples. Mo shows a very scattered plot. $\mathrm{Cu}, \mathrm{Zn}$ are immobile in most of the drillhole samples while they are totally lost in outcrop samples. $\mathrm{Pb}$ is enriched in all the samples. As, $\mathrm{Sb}$ and $\mathrm{Au}$ are considerably enriched in all the altered samples while the enrichment is significant in smectite rich samples, especially in samples $36 \mathrm{~m}, \mathrm{H} 335$ and H336. 
Table 5. Corelation coefficients of immobile elements.

\begin{tabular}{|c|c|c|c|c|c|c|c|c|c|c|c|c|}
\hline & $\mathrm{TiO}_{2}$ & $\mathrm{Al}_{2} \mathrm{O}_{3}$ & Sc & Ga & $\mathrm{Hf}$ & $\mathrm{Nb}$ & $\mathrm{Ta}$ & Th & $v$ & w & $\mathrm{Zr}$ & $Y$ \\
\hline $\mathrm{TiO}_{2}$ & 1.00 & & & & & & & & & & & \\
\hline $\mathrm{Al} 2 \mathrm{O}_{3}$ & 0,78 & 1.00 & & & & & & & & & & \\
\hline Sc & 0,82 & 0,92 & 1,00 & & & & & & & & & \\
\hline Ga & 0,79 & 0,87 & 0,94 & 1,00 & & & & & & & & \\
\hline $\mathrm{Hf}$ & 0,42 & 0,75 & 0,54 & 0,41 & 1,00 & & & & & & & \\
\hline $\mathrm{Nb}$ & $-0,18$ & $-0,61$ & $-0,68$ & $-0,58$ & $-0,42$ & 1,00 & & & & & & \\
\hline $\mathrm{Ta}$ & 0,24 & 0,19 & 0,15 & 0,31 & $-0,21$ & $-0,12$ & 1,00 & & & & & \\
\hline Th & $-0,31$ & 0,29 & 0,15 & 0,17 & 0,30 & $-0,51$ & 0,01 & 1,00 & & & & \\
\hline$v$ & 0,60 & 0,80 & 0,81 & 0,70 & 0,56 & $-0,59$ & $-0,24$ & 0,19 & 1,00 & & & \\
\hline$w$ & 0,48 & 0,68 & 0,72 & 0,57 & 0,39 & $-0,54$ & 0,04 & 0,49 & 0,60 & 1,00 & & \\
\hline $\mathrm{Zr}$ & 0,82 & 0,93 & 0,97 & 0,89 & 0,52 & $-0,62$ & 0,19 & 0,19 & 0,85 & 0,80 & 1,00 & \\
\hline$Y$ & $-0,75$ & $-0,57$ & $-0,66$ & $-0,83$ & $-0,08$ & 0,21 & $-0,46$ & 0,26 & $-0,41$ & $-0,09$ & $-0,59$ & 1,00 \\
\hline
\end{tabular}

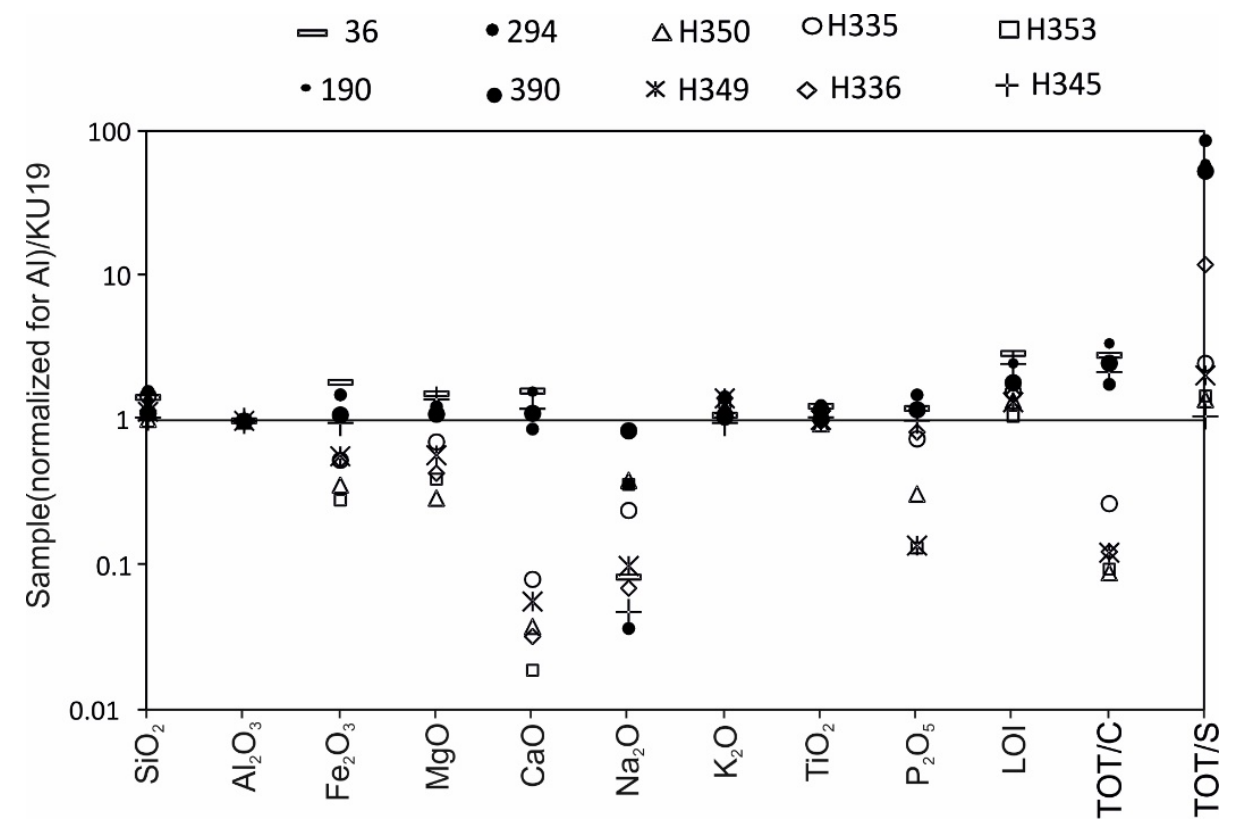

Figure 13. Diagram showing mobility of major elements.

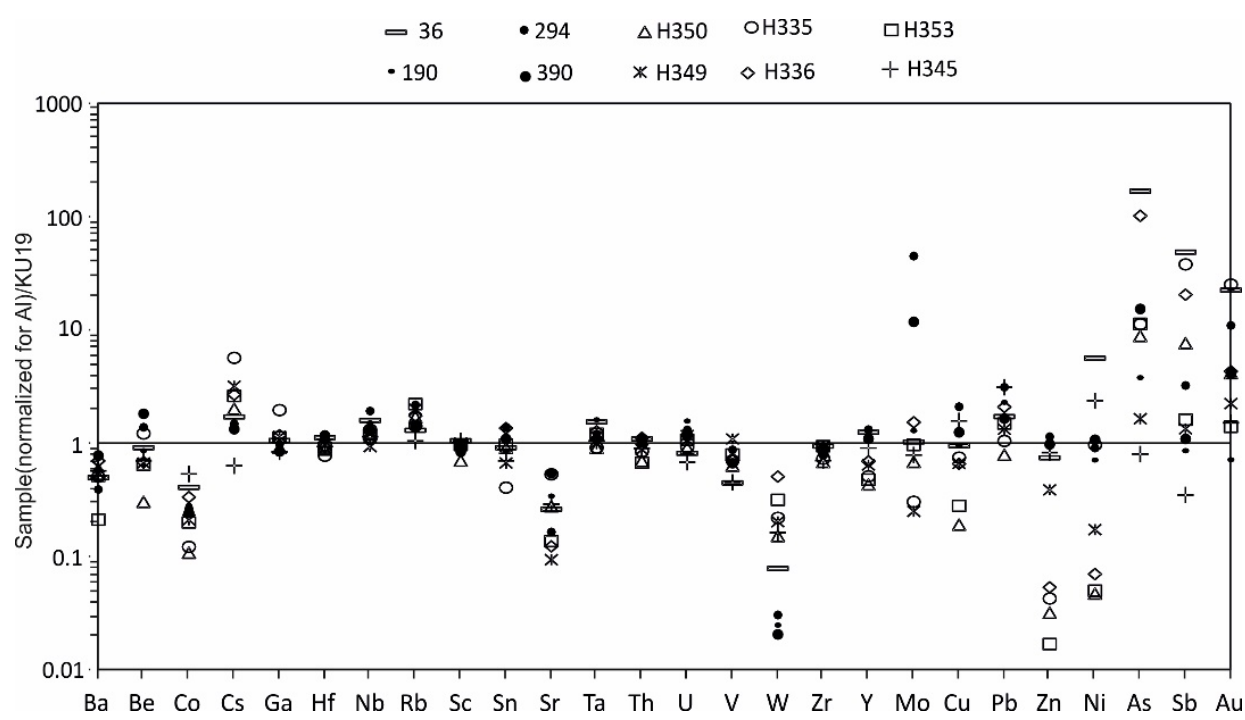

Figure 14. Diagram showing mobility trace elements. 


\subsection{Water geochemistry and activity diagrams}

Physical, chemical, $\mathrm{O}$ and $\mathrm{H}$ isotopic data of waters from Hisaralan geothermal field is given in Table 6. The surface temperatures of the thermal springs are in the range of $70-98^{\circ} \mathrm{C}$ and $\mathrm{EC}$ values are vary between 1340-1409 $\mu \mathrm{S} / \mathrm{c}$. The thermal waters belong to the $\mathrm{Na}-\mathrm{HCO}_{3}$ facieses while cold spring waters belong to the $\mathrm{Ca}-\mathrm{HCO}_{3}$ type. Low chloride content indicates shallow circulation for Hisaralan geothermal waters (Mutlu, 2007). Sindırgı geothermal waters plot on the immature waters and not attain a water rock equilibrium (Mutlu, 2007). Cation geothermometers are doubtful for immature waters (Giggenbach, 1998). So the silica geothermometers were used to determine the reservoir temperature. Geothermal fluids saturated with respect to quartz over $180^{\circ} \mathrm{C}$ while at lower temperatures chalcedony or amorphous silica is oversaturated (Arnorsson, 1975). The silica solubility is governed by amorphous silica and/or chalcedony.

The proposed temperature range is between 110 to $150{ }^{\circ} \mathrm{C}$ for Sindırgı geothermal waters (Mutlu, 2007). The chalcedony geothermometer agree well with mineral equilibrium calculations and
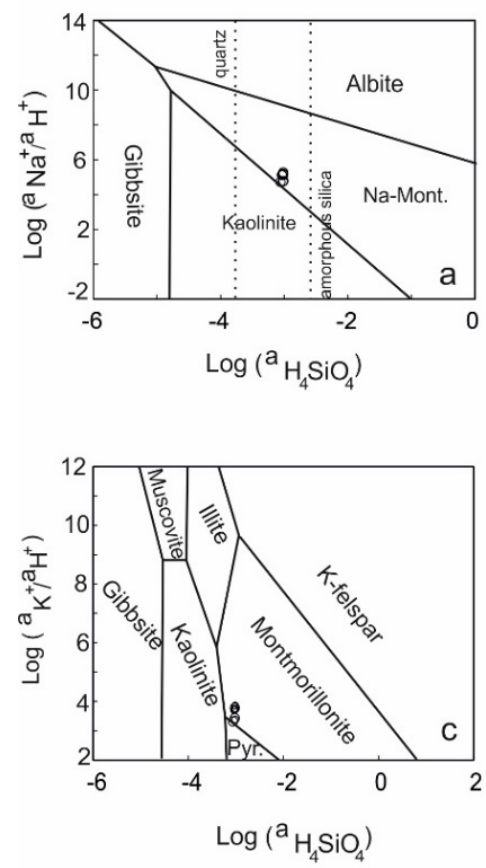

around $120{ }^{\circ} \mathrm{C}$ for Sindirgı geothermal waters (Mutlu and Kılıç, 2009).

The thermal water element activities were plotted on activity diagrams for the purpose of investigate mineral-fluid equilibrium in Hisaralan geothermal field. The diagrams were selected on the basis of clay mineralogy and temperature of drillhole and outcrop samples.

The thermal waters are in eqilibrium with $\mathrm{Na}$ and $\mathrm{Ca}$-montmorillonite in the diagrams prepared for $\mathrm{aca}^{2+} / \mathrm{a}^{2}{ }_{\mathrm{H}}$ and $\mathrm{aNa}^{+} / \mathrm{a}_{\mathrm{H}}{ }^{+}$against a ${ }_{\mathrm{H} 4 \mathrm{siO}}$. (Figure 15a, b; Tardy, 1971). According to clay mineralogy of Hisaralan geothermal field montmorillonite and illite are separate phases anda does not display a continious serie. So the water samples can be plotted on the diagram of $\mathrm{aK}_{\mathrm{K}}{ }^{+} / \mathrm{a}_{\mathrm{H}}{ }^{+}$against $\mathrm{a}_{\mathrm{H} 4 \mathrm{siO4}}$ prepared for discrete illite and montmorillonite (Figure 15c; Garrels, 1984). The thermal waters plot on the montmorillonite field. On the other hand, the binary diagrams which are prepared for activities at $100{ }^{\circ} \mathrm{C}$ and 1 bar conditions are plotted on the kaolinite field (Figure 11d, Merino, 1975). It is concluded that montmorillonite has been formed below $100^{\circ} \mathrm{C}$.
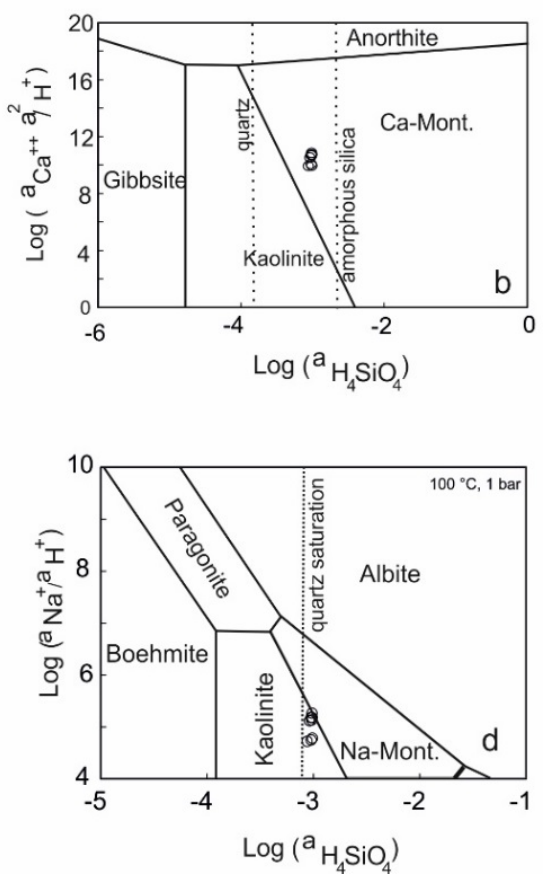

Figure 15. (a, b) The plot of activities of geothermal waters at $25^{\circ} \mathrm{C}$ (Tardy, 1971); (c) Mineral stability diagram taken from Garrels (1984); (d) Mineral stability diagrams at $100^{\circ} \mathrm{C}$ (Merino, 1975). 
Table 6. Physical chemical and isotopic data of waters from Hisaralan geothermal field. 1, 2, 3, 4, 6,7, 8 and 9: Thermal waters. 5: river water 10-11: cold spring waters.

\begin{tabular}{|c|c|c|c|c|c|c|c|c|c|c|c|c|c|c|c|}
\hline $\begin{array}{c}\text { Sample } \\
\text { no } \\
\end{array}$ & $\mathrm{pH}$ & $\mathrm{T}\left({ }^{\circ} \mathrm{C}\right)$ & EC & $\mathrm{dO}_{2}$ & $\mathrm{Na}$ & K & Mg & $\mathrm{Ca}$ & $\mathrm{Cl}$ & $\mathrm{SO}_{4}$ & HS & $\mathrm{HCO}_{3}$ & Si & $\delta D$ & $\delta^{18} O$ \\
\hline 1 & 6.75 & 97.0 & 1375 & 0.21 & 287.81 & 19.49 & 3.74 & 24.45 & 87 & 99 & 0.52 & 602.05 & 58.66 & 60.9 & 9.05 \\
\hline 2 & 7.10 & 94.0 & 1409 & 0.17 & 277.69 & 18.30 & 2.69 & 18.55 & 83 & 96 & 0.24 & 611.82 & 55.53 & 61.0 & 8.9 \\
\hline 3 & 7.17 & 98.0 & 1366 & 0.19 & 275.01 & 18.32 & 2.87 & 21.09 & 84 & 93 & 0.24 & 608.16 & 57.73 & 61.5 & 9.03 \\
\hline 4 & 6.73 & 70.0 & 1363 & 1.86 & 257.49 & 17.33 & 3.11 & 22.37 & 80 & 87 & - & 601.60 & 52.41 & 60.5 & 8.98 \\
\hline 5 & 8.20 & 11.0 & 469 & 10.05 & 11.05 & 3.26 & 19.65 & 63.99 & 9 & 33 & - & 272.33 & 7.06 & 54.8 & 8.95 \\
\hline 6 & 6.81 & 74.0 & 1364 & 2.17 & 278.00 & 18.49 & 2.91 & 21.68 & 85 & 93 & 0.04 & 601.60 & 57.13 & 60.6 & 9.08 \\
\hline 7 & 7.15 & 96.0 & 1375 & 1.45 & 284.63 & 19.03 & 2.95 & 23.42 & 87 & 93 & 0.06 & 613.65 & 58.83 & 60.9 & 8.93 \\
\hline 8 & 7.12 & 98.0 & 1358 & 0.23 & 272.73 & 17.91 & 2.88 & 22.16 & 84 & 93 & 0.06 & 598.39 & 58.14 & 61.3 & 8.99 \\
\hline 9 & 7.25 & 96.0 & 1340 & 0.60 & 275.55 & 18.16 & 3.4 & 19.32 & 84 & 93 & 0.16 & 590.45 & 58.85 & 60.9 & 9.05 \\
\hline 10 & 7.10 & 16.7 & 643 & 6.9 & 30.96 & 1.6 & 18.12 & 86.84 & 17 & 30 & - & 378.57 & 10.71 & 52.1 & 8.5 \\
\hline 11 & 7.07 & 25.7 & 701 & 6.81 & 31.15 & 1.57 & 25.75 & 91.48 & 17 & 36 & - & 415.21 & 11.50 & 52.3 & 8.5 \\
\hline
\end{tabular}

\subsection{Isotope Studies}

The $\delta \mathrm{D}$ and $\delta^{18} \mathrm{O}$ values of altered samples are given in Table 7. $\delta \mathrm{D}$ values are plotted against the $\delta^{18} \mathrm{O}$ values of the altered samples as well as thermal waters in Figure 16. The $\mathrm{O}$ and $\mathrm{H}$ isotope values of thermal waters fall between the Global Meteoric Water Line (GMWL) and Marmara Meteoric Water Line (MMWL). This indicates a meteoric origin for Hisaralan geothermal waters.

Table 7. $\delta \mathrm{D}$ and $\delta^{18} \mathrm{O}$ values of altered samples.

\begin{tabular}{lcc}
\hline Sample No & $\boldsymbol{\delta D}$ & $\boldsymbol{\delta}^{\mathbf{1 8}} \mathbf{O}$ \\
\hline $48 m$ & -83 & 3.4 \\
$190 m$ & -90 & 2.2 \\
$254 m$ & -82 & 2.0 \\
$296 m$ & -90 & -0.9 \\
$436 m$ & -89 & 0.5 \\
H335 & -72 & 3.7 \\
H350 & -84 & 7.2 \\
KA & -96 & 2.2 \\
KU & -91 & 2.2 \\
\hline
\end{tabular}

Clay fraction of HS-2 drillhole samples $48 \mathrm{~m}, 190 \mathrm{~m}$, $254 \mathrm{~m}, 296 \mathrm{~m}$ and $436 \mathrm{~m}$ from deeper levels to the shallower parts and outcrop samples H335, H350, KA and $\mathrm{KU}$ were studied. The drillhole samples $\delta^{18} \mathrm{O}$ values increases with depth. $\delta^{18} \mathrm{O}$ value of $296 \mathrm{~m}$ is lower than $436 \mathrm{~m}$ and $296 \mathrm{~m}$ has also the lowest $\delta^{18} \mathrm{O}$ value. This is probably due to the small amount of smectite content of $436 \mathrm{~m}$ (see Figure 5). The $\delta^{18} \mathrm{O}$ values of $190 \mathrm{~m}, 254 \mathrm{~m}, \mathrm{KA}$ and $\mathrm{KU}$ are higher than these two samples and very close to each other. This is probably due to the high amount of swelling layers of $\mathrm{I}-\mathrm{S}$ in these samples. Higher amount of illite in I-S should be due to the increasing temperature and/or illite crystalinity with increasing depth. The smectite and I-S dominated sample 48 and $\mathrm{H} 335$ has the highest $\delta^{18} \mathrm{O}$ value. The higher oxygen isotope ratio of smectite dominant samples should be due to the lowest formation temperature of smectite (Marumo, 1989). The $\delta D$ values range from -71 and $-65 \%$ and the $\delta^{18} \mathrm{O}$ values $+4,5$ and $+6,1 \%$ of smectite in Noboritsu active geothermal system points to crystallisation at lower temperatures between $100-150^{\circ} \mathrm{C}$ (Marumo et al. 1995). The $\delta \mathrm{D}$ and $\delta^{18} \mathrm{O}$ values for $\mathrm{H} 335$ confirm a low formation temperature for highly smectite bearing sample.

The highest $\delta^{18} \mathrm{O}$ value belongs to the halloysite bearing sample $\mathrm{H} 350$ and this indicates the lowest 
formation temperature. Even $\mathrm{H} 350$ has high illite content which is inferred from the XRD peaks, the plot is very close to the kaolinite line. It is indicated that halloysite probably falls to the right side of supergene line (demonstrated by the arrow) and is formed by low temperature meteoric waters and has a supergene origin.

The fluid temperatures which clay minerals formed were determined for the most pure clay mineral (illite and/or I-S) bearing samples $(296 \mathrm{~m}$ and $\mathrm{KU}$ ). The oxygen isotope ratios of fluid in equilibrium with illite at 200 and $250^{\circ} \mathrm{C}$ for sample
$296 \mathrm{~m}$ and $175-200{ }^{\circ} \mathrm{C}$ for KU was calculated by using illite-water fractionation factor $(\alpha)$ and the equation is as follows: $10^{3} \ln (\alpha)=2.39 * 10^{6} / \mathrm{T}^{2}$ 3.76 (Sheppard and Gilg, 1996). The hydrogen isotope ratio was calculated by the equation $10^{3} \mathrm{In}$ $(\alpha)=-20 \pm 5$. The calculated $\delta^{18} O$ and $\delta D$ values of fluids in equilibrium with illites are plotted in Figure 16. The fluids are somewhat enriched in $\delta^{18} \mathrm{O}$. The enrichment displays a simple water-rock interaction.

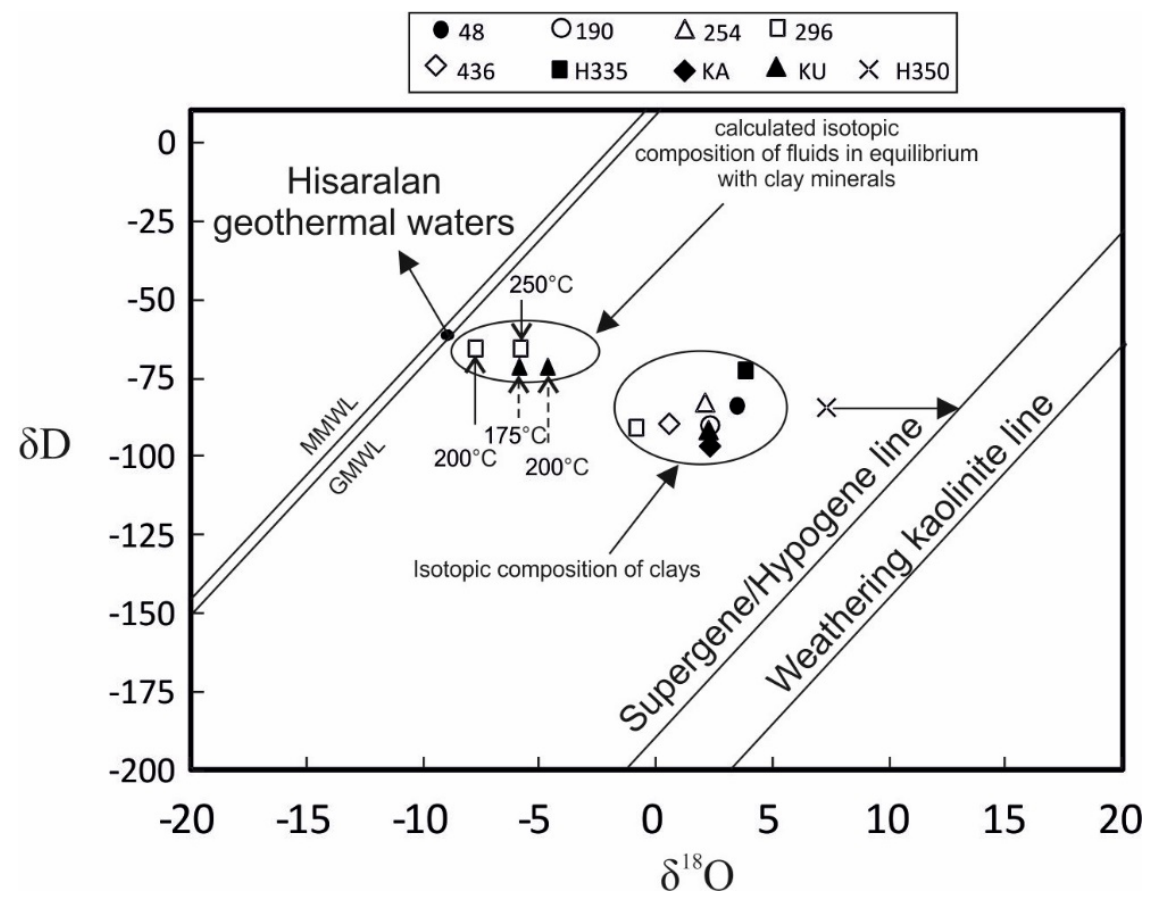

Figure 16. $\delta^{18} \mathrm{O}$ versus $\delta \mathrm{D}$ for HS-2 drillhole samples and waters from Hisaralan geothermal field. Supergene versus hypogene lines (S/H) from Sheppard et al. (1969) and kaolinite line from Sheppard and Gilg (1996). Global Meteoric water line $\left(\delta D=8 \delta^{18} \mathrm{O}+10\right)\left(\right.$ Craig, 1961). Mediterranean Meteoric Water Line $\left(\delta D=8 \delta^{18} \mathrm{O}+22\right)(\mathrm{Gat}$ and Carmi, 1970). Close circles presents thermal waters.

\subsection{1. $R b$-Sr isotope analyses}

The data of illitic clays is given in Table and $\mathrm{Rb}-\mathrm{Sr}$ isocron diagram is plotted on Figure. Data for four I-S samples shows a linear ship with a slope which corresponds to $17,4 \pm 1,9 \mathrm{Ma}$ (MSWD=0.27) with an initial ${ }^{87} \mathrm{Sr} /{ }^{86} \mathrm{Sr}$ ratio of $0,70925 \pm 0,00077$ (Figure 17). This indicates the pure I-S of different illite contents were formed synchronously.
Table 8: $\mathrm{Rb}-\mathrm{Sr}$ data of illitic minerals (illite and/or I-S).

\begin{tabular}{ccccc}
\hline & $\mathrm{Rb}(\mathrm{ppm})$ & $\mathrm{Sr}(\mathrm{ppm})$ & ${ }^{87} \mathrm{Rb} /{ }^{86} \mathrm{Sr}$ & ${ }^{87} \mathrm{Sr} /{ }^{86} \mathrm{Sr}$ \\
\hline $\mathbf{1}$ & 258.313 & 84.40 & 8.857 & 0.71157555 \\
$\mathbf{2}$ & 252.796 & 43.14 & 16.962 & 0.713239014 \\
$\mathbf{3}$ & 304.105 & 25,35 & 34.736 & 0.717933492 \\
$\mathbf{4}$ & 393.049 & 27.68 & 41.119 & 0.719395648 \\
\hline
\end{tabular}




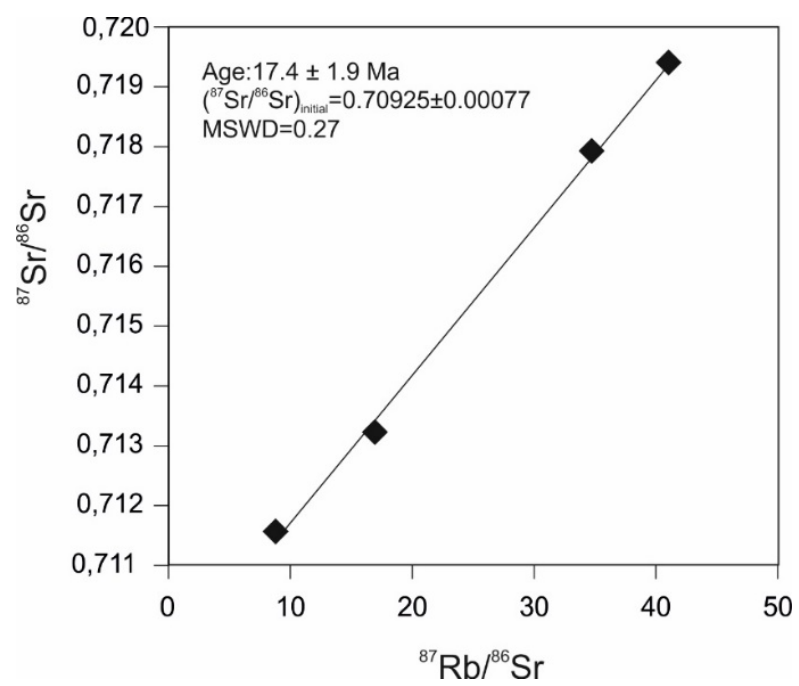

Figure 17: $\mathrm{Rb}-\mathrm{Sr}$ isocron plot for the clay fractions $(<2 \mu \mathrm{m})$ of illites.

\section{Discussion}

The Hisaralan geothermal field characterized by dominance of sericitic minerals (illite and/or I-S) accompanied by adularia and quartz (silicification) .This type of deposits refer to adularia-sericite (or low sulfidation) and form in geothermal systems near neutral $\mathrm{pH}$, chloride brines in a lateral flow regime high above from a heat source (Heald et al.,1987). The occurrence of adularia and sericite indicate $250{ }^{\circ} \mathrm{C}$ temperature due to the feldspar hydrolysis (Hemley and Jones, 1964). There are gold bearing epithermal quartz veins close to the geothermal field (Yilmaz et al., 2013). Some of these veins extent up to the Hisaralan geothermal field. It is concluded that the fossil hydrothermal alteration in geothermal field is contemporaneously developed and effected by these epithermal systems. The Rb-Sr ages of 17.4 $\pm 1.9 \mathrm{Ma}$ is compatible with the $\operatorname{Ar}-\operatorname{Ar}$ ages $18.3 \pm$ $0.2 \mathrm{Ma}$ of the Kızıltepe mineralization from quartz adularia veins near Hisaralan(Yılmaz et al., 2013).

The clay mineralogy of Hisaralan geothermal field is characterized by a vertical distribution. R3 I-S ,discrete illite and chlorite are the dominant clay minerals in the deeper parts of the volcanic sequence. Smectite and R2 I-S are dominant clay minerals from $120 \mathrm{~m}$ up to the surface. In addition, the percent of expandable component of I-S and amount of smectite progressively increase getting close to the surface.

The fossil hydrothermal alteration occurred in two stages. The first one, propylitic alteration is a weak or incipient alteration and characterized by epidote, chlorite, carbonates, albite and pyrite (Hemley and Jones, 1964). The mineral assemblage of the propylitic alteration consists of chlorite, calcite, and pyrite in Hisaralan geothermal field. Chlorite was formed by pervasive alteration. The mineral assemblage forms at small $\mathrm{w} / \mathrm{r}$ ratio in rock dominated system and bulk composition is change very little from the primary rock (Reed, 1997). Epidote is common in low $\mathrm{CO}_{2}$ systems while calcite is abundant in high $\mathrm{CO}_{2}$ (Elders et al., 1978). Fluids higher in $\mathrm{CO}_{2}$ leads to calcite instead of epidote (Browne and Ellis, 1970). Thus, a high $\mathrm{CO}_{2}$ system was prevailed during hydrothermal alteration in Hisaralan. Calcite may be occurred by the altering fluid which introduced bicarbonate to the system (Hedenquist, 1990). The chlorite chemistry can not be used as geothermometer but the high amount of $\mathrm{Fe} / \mathrm{Mg}$ is an indicative of high temperature occurrence of chlorite at $250^{\circ} \mathrm{C}$. The formation of discrete illite gives a temperature range higher than $230^{\circ} \mathrm{C}$ (Reyes, 1990). Chlorite should probably be formed higher than this temperature.

In the second stage, propyllitic alteration was postdated by sericitic alteration (illite and/or I-S). Sericitic minerals occur by transformation of albite as well as volcanic glass. The silicification and secondary quartz is associated with illite. The illitisation of $\mathrm{Na}$-plagioclase requires $\mathrm{K}^{+}$which can be provided by chloritization of biotite or dissolution of K-feldspar (Sanidine). On the other hand, illitic minerals (illite and/or I-S) can be seen in the micro cracks of the altered dacitic pyroclastics as veinlets. 
The last stage of alteration is characterized by modern precipitates as dioctahedral smectite (probably montmorilonite), halloysite, and hematite. Alteration to montmorillonite occurs at temperatures $100-120^{\circ} \mathrm{C}$ (Henley and Ellis, 1983). Low temperature hydrothermal dioctahedral smectites has been referred close to the surface of the geothermal fields (Cole, 1988; Mizoto, 1998; Mas, 2003;). On the other hand, synthesis of dioctahedral smectite is achieved under elevated temperatures (Tomita, 1993). The activity diagrams indicate that geothermal waters are in equilibrium with smectite below $100{ }^{\circ} \mathrm{C}$ while kaolinite should be formed above $100{ }^{\circ} \mathrm{C}$. The smectite rich surface and shallow level drillhole samples which contains high amount of smectite are compatible with the geothermal water in equilibrium with smectite.. The formation of both smectite and hematite has been precipitated from geothermal fluids. There is no evidence of transformation from plagioclase or volcanic glass and it is also supported by SEM. On the other hand, halloysite is formed by supergene meteoric fluids of low temperature in microcracks of the altered rocks. This is supported by $\mathrm{O}$ and $\mathrm{H}$ isotop analysis which is plotted close to the supergene/hypogene kaolinite line despite the high amount of illite minerals.

The smectite bearing samples also show a considerabile enrichment in $\mathrm{As}, \mathrm{Sb}$ and $\mathrm{Au}$ in regard to other alteration products.

The hydrogen and oxygen isotope studies reveal that smectite is formed at much lower temperatures than illite. The $\delta^{18} \mathrm{O}$ values of the HS-2 drillhole samples decrease with increasing depth. The isotope data also reveal occurrence of halloysite from meteoric waters.

\section{Conclusions}

The Hisaralan geothermal field exposed to at least three stages of hydrothermal alteration. The two stages are coeval and cogenetic with Early
Miocene volcanism. Illite , I-S and chlorite are the dominant alteration minerals of these phases. The first stage of alteration is prophyllitic alteration and represented by chlorite and calcite. The second stage of alteration is sericitic alteration and represented by illite, illite rich I-S, quartz and adularia. Propylitic alteration is postdated by sericitic alteration. The Rb-Sr analysis reveals the sericitic phase is Early Miocene and directly related to the volcanism.

The last stage of hydrothermal alteration is related to the present day geothermal waters. The activity diagrams in equilibrium with smectite among the other clay minerals and lack of any relation of smectite with other minerals indicates direct precipitation from solutions. The high amount of As content in smectite is also an indication for smectite. The hematite is probably associated with smectite and represents oxidizing conditions close to the surface. The tabular halloysite is a supergene alteration product and precipitated from low temperature meteoric waters.

The conjunction of Simav graben and IBTZ and existence of smectite in these lines can be used as exploration tool for finding new geothermal waters nearby the Hisaralan (Sındırgı) district.

\section{Acknowledgemends}

We are thankful to TÜBITAK for financial support by the project 109Y171. The authors are greatful to Turkish Petroleum (TP) for providing the drillhole datum and samples.

\section{References}

Aagaard, P. and Helgeson, H.C., 1983. Activity/composition relations among silicates and aqueous solutions:II, Chemical and thermodynamic consequences of ideal mixing of atoms on homological sites in montmorillonites, illites, and mixed-layer clays. Clays and Clay Minerals, 31, 207217. 
Aja, S.U. and Rosenberg, P.E., 1992. The thermodynamic status of compositionally variable clay minerals: a discussion. Clays and Clay Minerals, 40, 292-299.

Arnorsson, S., 1975. Application of silica geothermometer in low-temperature hydrothermal areas of Iceland. American Journal of Science, 275, 763-784.

Beaufort, B., Westercamp, D., Legendre, O., \& Meunier, A., 1990). The fossil hydrothermal system of Saint Martin, Lesser Antilles: geology and lateral distribution of alterations. Journal of Volcanology and Geothermal Research, 40, 219-243.

Bethke, C.M., Vergo, N. and Altaner, S.P., 1986 Pathways of smectite illitization: Clays and Clay Minerals, 34, 125- 135.

Bozkurt, E., 2001. Neotectonics of Turkey-a synthesis. Geodinamica Acta, 14, 3-30.

Brown G. and Brindley G.W., 1980. X-ray diffraction procedures for clay mineral identification. in: Crystal Structures of Clay Minerals and their X-ray Identification (G.W. Brindley \& G., Brown, editors). Monograph 5. Mineralogical Society, London, 305359.

Browne, P.R.L. and Ellis, A.J., 1970. The OhakiBroadlands hydrothermal area, New Zealand: Mineralogy and related geochemistry. American Journal of Science, 269, 97-215.

Cathelineau, M. and Nieva, D., 1985. A chlorite solid solution geothermometer. The Los Azufres (Mexico) geothermal system. Contribution to Mineralogy and Petrology, 91, 235-244.

Clayton, R.N. and Mayeda, T.K., 1963. The use of bromine pentafluoride in the extraction of oxygen from oxides and silicates for isotopic analysis. Geochimica et Cosmochimica Acta, 27, 43-52.

Cole, T.G., 1988. The nature and the origin of smectite in the Atlantic II Deep, Red Sea. Canadian Mineralogist, 26, 755-763.

Craig, H., 1961.Isotopic variations in meteoric waters. Science, 133, 1702-1703.
Çoban H., Karacık Z. and Ece Ö.I., 2012. The role of slab roll-back and extensional collapse on the generation of coexisting early to middle Miocene alkaline and calc-alkaline back-arc magmas in western Anatolia extensional province; a record from Simav (Uşak) region, Turkey. Lithos, 140, 119-141.

Ece, Ö. I., Ekinci, B., Schroeder, P.A., Crowe D. and Esenli, F., 2013. Origin of the Düvertepe kaolinalunite deposits in Simav Graben, Turkey: Timing and styles of hydrothermal mineralization. Journal of Volcanology and Geothermal Research. 255, 5778.

Ece, Ö .I. and Schroeder, P.A., 2007. Clay mineralogy and chemistry of the halloysite and alunite deposits in the Turplu area, Balıkesir, Turkey. Clays and Clay Minerals, 55, 18-36.

Elders, W.A., Hoagland, J.R. and Olson, E.R., 1978. Hydrothermal mineralogy and isotopic geochemistry in Cerro Prieto geothermal field, III, Practical Appication, Geothermal Sources Concil, Transactions, 2, 177-179.

Ercan, T., Çevikbaş, A., Günay, E., Ateş, M., Can, B., Küçükayman, A. And Erkan, M., 1984. Bigadiç çevresinin (Balıkesir) jeolojisi ve magmatik kayaçların petrolojisi, Türkiye Jeoloji Kurumu Bülteni, 5, 75-85.

Erkul, F., Helvacı, C. and Sözbilir, H., 2005. Evidence for two episodes of volcanism in the Bigadiç borate basin and tectonic implications for western Turkey. Geological Journal, 40, 545-570.

Essene, E.J. and Peacor, D.R., 1995. Clay mineral thermometry. A critical perspective. Clays and Clay Minerals, 43, 540-553.

Garrels, R. M., 1984. Montmorillonite/illite stability diagrams. Clays and Clay Minerals, 32, 161-166.

Gat, J.R. and Carmi, I., 1970. Evolution in the isotopic composition of atmospheric waters in the Mediterrenean Sea area. Journal of Geophysical Research, 75, 3039-3048. 
Giggenbach, W.F., 1988. Geothermal solute equilibria. Derivation of $\mathrm{Na}-\mathrm{K}-\mathrm{Ca}-\mathrm{Mg}$ geoindicators. Geochimica et Cosmochimica Acta, 52, 2749-2765.

Grant., J.A., 1986. The isocon diagram: A simple solution to Gresens' equation for metasomatic alteration. Economic Geology, 81, 1976-1982.

Gresens R.L., 1967. Composition-volume relationship of metasomatism. Chemical Geology, 2, 47-65.

Harvey, C.C., Browne, P.R., 1991. Mixed-layer clay geothermometry in the Wairakei geothermal field, New Zealand. Clays and Clay Minerals, 39, 614-621.

Heald, P., Foley, N.K. and Hayba, D.O., 1987. Comparative anatomy of volcanic-hosted epithermal deposits: acid-sulphate and adularia sericite types. Economic Geology, 82, 1-26.

Hedenquist, J.W., 1990. The thermal and geochemical structure of theBroadlands-Ohaaki geothermal system, New Zealand. Geothermics, 19, 151-185.

Helvacı, C., 1995. Stratigraphy, mineralogy and genesis of the Bigadiç borate deposits, western Turkey, Economic Geology, 90, 1237-1260.

Hemley, J.J. and Jones, W.R., 1964. Chemical aspects of hydrothermal alteration with emphasis on hydrogen metasomatism. Economic Geology, 59, 538-569.

Henley, R. W. and Ellis, A. J., (1983). Geothermal systems ancient and modern: A geochemical review. Earth-Science Reviews, 19, 1-50.

Horton, D.G., 1985. Mixed layer illite/smectite as a paleotemperature indicator in the Amethyst vein system, Creede district, Colorado, USA. Contributions to Mineralogy and Petrology, 91, 17I179.

Inoue, A., Meunier, A. and Beaufort, D. 2004. Illitesmectite mixed-layer minerals in felsic volcaniclastic rocks from drill cores, Kakkonda, Japan. Clays and Clay Minerals, 52, 66-84.

Inoue, A., Kohyama, N., Kitagawa, R. and Watanabe, T., 1987. Chemical and morphological evidence for the conrvesion of smectite to illite. Clays and Clay Minerals, 35, 111-120.

Inoue, A. and Utada M., 1983 .Further investigations of a conversion series of dioctahedral mica/smectites in the Shinzan hydrothermal alteration area, northeast Japan. Clays and Clay Minerals, 31, 401.

Keller, W. D., Reynolds, R.C. and Inoue, A., 1986. Morphology of clay minerals in the smectite-toillite conversion series by scanning electron microscopy. Clays and Clay Minerals, 34, 187-197.

Ludwig, K., 1996. Isoplot, Version 2.9. U.S. Geol. Surv., Open-file, Rep, 91-445.

MacLean W.H. and Kranidiotis P., 1987. Immobile elements as monitors of mass transport in hydrothermal alteration: Phelps Dodge massive sulfide deposit, Matagami. Economic Geology, 82, 951-962.

Martinez-Serrano, R.G., Dubois, M., 1998. Chemical variations in chlorite at the Los Humeros geothermal system, Mexico. Clays and Clay Minerals, 46, 615-628.

Marumo, K., 1989. Genesis of kaolin minerals and pyrophyllite in Kuroko deposits of Japan: Implications for the origins of the hydrothermal fluids from mineralogical and stable isotope data, Geochimica et Cosmochimica Acta, 53, 2915-2924.

Marumo, K., Longstaffe, F. J. and Matsubaya, O., 1995 Stable isotope geochemistry of clay minerals from fossil and active hydrothermal systems, southwestern Hokkaido, Japan. Geochimica et Cosmochimica Acta, 59, 2545-2559.

Mas, A., Guisseau, D., Patrier Mas P., Beaufort, D., Genter, A., Sanjuan, B., Girard J.P., 2006. Clay minerals related to the hydrothermal activity of the Bouillante geothermal field (Guadeloupe), Journal of Volcanology and Geothermal Research, 158, 380400.

Mas, A., Patrier, P., Beaufort, D. and Genter, A., 2003. Clay-mineral signatures of fossil and active hydrothermal circulations in the geothermal system of the Lamentin Plain, Martinique. Journal of 
Volcanology and Geothermal Research, 124, 195218.

Merino, E., 1975 Diagenesis in Tertiary sandstones from Kettleman North Dome, California-II. Interstitial solutions: distribution of aqueous species at $100^{\circ} \mathrm{C}$ and chemical relation to the diagenetic mineralogy. Geochimica et Cosmochimica Acta, 39, 1629-1645.

Mizota, C. and Faure, K. 1998. Hydrothermal origin of smectite in volcanic ash. Clays and Clay Minerals, 46, 178-182.

Moore, D.M. and Reynolds, R.C., 1997. X-Ray Diffraction and the Identification and Analysis of Clay Minerals, Oxford University Press, New York. 235-273

Mutlu, H. and Kılıç, A., 2009. Geothermometry applications for the Balıkesir geothermal waters. Environmantal Geology, 56, 913-920.

Mutlu., H., 2007. Constraints on the origin of the Balıkesir thermal waters (Turkey) from stable isotope $\left(d^{18} \mathrm{O}, \mathrm{dD}, \mathrm{d}^{13} \mathrm{C}, \mathrm{d}^{34} \mathrm{~S}\right)$ and major-trace element compositions. Turkish Journal of Earth Sciences, 15, 13-32.

Mutlu, H. and Sariz, K., 2005. Geochemistry and origin of the Şaphane alunite deposits, western Anatolia, Turkey, Ore Geology Reviews, 26, 39-50.

Nadeau, P H., and Reynolds, R C. (1981) Burial and contact metamorphism in the Mancos shale. Clays and Clay Minerals, 29,249-259

Niu, Y. and Batiza, R., 1997. Trace element evidence from seamounts for recycled oceanic crust in the Eastern Pacific mantle. Earth and Planetary Science Letters, 148, 471-483.

Ohta, T. and Arai, H., 2007. Statistical empirical index of chemical weathering in igneous rocks: A new tool for evaluating the degree of weathering, Chemical Geology, 240, 280-297.

Okay, A.Ü. and Siyako, M., 1991. The revised location of the Izmir-Ankara suture in the region between Balıkesir and Izmir. In: TURGUT, S. (ed), Tectonics and Hydrocarbon Potential of Anatolia and
Surrounding Regions, 333-355 [in Turkish with English abstract].

Oygür, V. ve Erler, A., 2000. Simav grabeninin metalojenisi (İç-Batı Anadolu, Türkiye) Türkiye Jeoloji Bülteni, 43, 7-19.

Özkaymak, Ç. and Sözbilir, H., 2008. Stratigraphic and structural evidence for fault re-activation: the active Manisa fault zone, western Anatolia. Turkish Journal of Earth Sciences, 17, 615-635.

Papoulis, D., Katagas, P.T. and Katagas, C., 2004. Progressive satages in the formation of kaolin minerals of different morphologies in the weathering of plagioclase. 52, 275-286.

Pollastro, R.,M. 1985. Mineralogical and morphological evidence for the formation of illite at the expense of illite/ smectite. Clays and Clay Minerals. 33, 265274.

Reed, M.H., 1997, Hydrothermal alteration and its relationship to ore fluid composition, in Barnes, H.L., ed., Geochemistry of hydrothermal ore deposits, 3rd ed.: Wiley, New York, 303-365.

Reyes, A.G., 1990. Petrology of Philippine geothermal systems and the application of alteration mineralogy to their assessment. Journal of Volcanology and Geothermal Research, 43, 279309.

Seyitoğlu, G., 1997. The Simav Graben: an example of young E-Wtrending structures in the Late extensional system of Western Turkey. Turkish Journal of Earth Sciences, 6, 135-141.

Shao, J., Yang, S. and Li, C., 2012. Chemical indices (CIA and WIP) as proxies for integrated chemical weathering in China: Inferences from analysis of fluvial sediments. Sedimetary Geology. 265-266, 110-120.

Sheppard, S.M.F. and Gilg, H.A., 1996. Stable isotope geochemistry of clay minerals. Clay Minerals, 31, 1 -24 .

Sheppard, S.M.F., Nielsen, R.L. and Taylor, H.P., 1969. Oxygen and hydrogen isotope ratio of clay minerals 
from porphyry copper deposits. Economic Geology,

64, 755-777.

Steiner, A., 1968. Clay minerals in hydrothermally altered rocks at Wairakei, New Zealand. Clays \& Clay Minerals, 16, 193-213.

Srodon, J. 1980. Precise identification ofillite/smectite interstratifications by X-ray powder diffraction: Clays and Clay Minerals, 28, 401.

Srodon, J. 1984 X-ray diffraction of illitic materials. Clays and Clay Minerals, 32, 337-349.

Tardy, Y., 1971. Characterization of the principal weathering types by the geochemistry of water from some European and African crystalline massifs. Chemical Geology, 7, 253-271.

Tomita, K., Yamane, H. and Kawano, M., 1993. Synthesis of smectite from volcanic glass at low temperature. Clays and Clay Minerals, 41, 655-661.

Uzel, B. and Sözbilir, H., 2008. A first record of strikeslip basin in western Anatolia and its tectonic implication: the Cumaovası basin as an example. Turkish Journal of Earth Sciences, 17, 559-591.

Valley., J.W, Kitchen, N., Kohn, M.J. and Niendorf C.R. and Spicuzza, M.J., 1995. UWG-2, a garnet standard for oxygen isotope ratios: strategies for high precision and accuracy with laser heating. Geochimica et Cosmochimica Acta, 59, 5223-5231.

Watanabe,T., 1981. Identification of illite/ montmorillonite interstratifications by X-ray powder diffraction. Journal of the Mineralogical Society of Japan, Special Issue, 15, 32-41 (in Japanese).

Yılmaz, H., Sönmez, N. F., Akay, E., Şener, A. K., Tufan, S.T., 2013. Low-Sulfidation Epithermal Au-Ag Mineralization in the Sındırgı District, Balıkesir Province, Turkey, Turkish Journal of Earth Sciences ,22, 485-522. 